Two LIPs and two Earth system crises: the impact of the North Atlantic Igneous Province and the Siberian Traps on the Earth-surface carbon cycle

\begin{tabular}{|r|l|}
\hline Journal: & Geological Magazine \\
\hline Manuscript ID: & GEO-14-1244.R1 \\
\hline Manuscript Type: & Article \\
\hline Date Submitted by the Author: & n/a \\
\hline Complete List of Authors: & Saunders, Andrew; University of Leicester, Department of Geology \\
\hline Keywords: & Large igneous province, mass extinction, hyperthermal, carbon cycle \\
\hline & \\
\hline
\end{tabular}




\section{Two LIPs and two Earth system crises: the impact of the North Atlantic Igneous Province and the Siberian Traps on the Earth-surface carbon cycle}

ANDREW D. SAUNDERS

Department of Geology, University of Leicester, Leicester LE1 7RH

Address for correspondence: ads@le.ac.uk 


\begin{abstract}
The links between the Siberian Traps and the end-Permian mass extinction, and between the North Atlantic Igneous Province (NAIP) and the Palaeocene-Eocene Thermal Maximum (PETM), demonstrate a critical role for large-igneous provinces (LIPs) in the disruption of the Earth-system carbon cycle (ESCC). High-precision age dates for both volcanic provinces and the associated environmental crises show that in both cases, the crisis was contemporaneous with the volcanism. The NAIP comprises two phases: the earlier Phase 1 ( $\sim 61 \mathrm{Ma})$, and the much more voluminous Phase $2, \sim 56$ Ma, linked to the opening of the NE Atlantic. The latter triggered the PETM, the largest Cenozoic hyperthermal. The Siberian Traps are significantly more voluminous than the NAIP, and triggered the end-Permian mass extinction. The masses of volcanic $\mathrm{CO}_{2}$ emitted from these provinces may have been much greater than previously suggested, because substantial gas may come from intrusive bodies deep within the crust (cryptic degassing: Armstrong McKay et al., 2014). Precursory warming due to the accumulation of volcanic $\mathrm{CO}_{2}$ in the atmosphere likely triggered the release of low- $\delta^{13} \mathrm{C}$ methane hydrate, although the masses of methane hydrate alone may have been insufficient to account for the observed temperature rises; the organic $\mathrm{C}$ was likely strongly supplemented by magmatically-derived carbon and thermogenic carbon released during emplacement of sills and dykes into C-rich sedimentary units. More data are required on the volcanic flux rates in order to refine the cause-effect relationships between LIPs and the ESCC.
\end{abstract}




\section{Introduction}

The causes of mass extinctions have been debated for over two centuries. They have been reviewed in innumerable papers and books, including those authored by the honorand of this volume (e.g., Hallam \& Wignall, 1997; Hallam, 2005). Extinctions are a modern zeitgeist, with existential threats from global warming, meteorite impacts, pandemics and nuclear war, but they have been important in the evolution of life and, to geologists, by providing important marker horizons throughout the Phanerozoic Eon. They also have the potential to inform about the effects of current and predicted climate change.

There is a growing consensus that mass extinctions are a consequence of catastrophic and rapid changes in the Earth-Surface Carbon Cycle (ESCC). These changes cannot be easily explained by processes that operate on a geologically long time scale (e.g., sealevel rise or fall; plate movement leading to formation of mountain belts or blocking of ocean circulation systems), so attention has turned to more dramatic triggers such as meteorite or comet impacts, flood basalts eruptions, and extra-solar events such as gamma-ray bursts (Thomas et al., 2005). Whether or not gamma-ray bursts are a trigger mechanism is virtually untestable; but at least one impact event coincides with one mass extinction (Chicxulub and the end-Cretaceous mass extinction) (Schulte et al., 2010).

Following the discovery of an iridium anomaly and other indicators of an extraterrestrial input at the end-Cretaceous, Alvarez et al. (1980) proposed that a meteorite impact caused the end-Cretaceous mass extinction. This arguably made decades of research into the causes of the extinction redundant virtually overnight, whilst simultaneously kickstarting searches for impact sites and the terrestrial effects of 
impactors. Whilst the latter certainly occurred, the former turned out not to be true; alternative models refused to go extinct. In the aftermath of the Alvarez study, for example, several papers argued that the evidence for impact could also be explained by flood basalt volcanism (e.g., Officer \& Drake, 1983, 1985; Officer et al., 1987). However, the discovery of the impact site in the Yucatan Peninsula and innumerable subsequent studies strengthened the case for an impact, at least for the end-Cretaceous extinction, and culminated in the 'guilty as proven' review of Schulte et al. (2010).

Confirmation that meteorite or comet impacts caused other mass extinctions or dramatic changes to the ESCC has proved elusive (White and Saunders, 2005; Racki, 2012), although they have been proposed for both the end-Permian (Becker et al., 2001) and end-Palaeocene (Kent et al., 2003) events. However, there has been a steady and growing argument that flood basalts (or the more embracing category of 'large igneous provinces', which include oceanic plateaus such as the Ontong Java Plateau) were the primary cause of many mass extinctions and other Earth-system crises, rather than meteorite impacts.

The term flood basalt was introduced by Tyrrell (1937), following the evocative description of Geikie (1903): '....there have been periods in the earth's history when the crust was rent by innumerable fissures over areas of thousands of square miles in extent, and when the molten rock.... welled out from these rents .... and flooded enormous tracts of country without forming any mountain or conspicuous volcanic cone...' Such events may rapidly pollute the Earth's surface, via a number of processes. Vogt (1972) was one of the first to associate flood basalts (and mantle plume activity) with mass extinction events, suggesting that the introduction of toxic concentrations of trace metals in the oceans was the 'kill' mechanism. McLean (1985), focussing on the effects of volcanic 
$\mathrm{CO}_{2}$, has been a strong advocate for the Deccan Traps as the cause of the end-Cretaceous mass extinction even in the face of strong opposition. Other workers have emphasised the role of volcanic $\mathrm{SO}_{2}$ and sulphate aerosols in generating volcanic winters where surface temperatures would plummet for short intervals of time (Stothers et al., 1986; Rampino, Self \& Stothers, 1988; Saunders and Reichow, 2009; Mussard et al., 2014). Furthermore, the inventory and volume of volatiles released by the volcanic activity may be considerably enhanced by injection of sills into evaporates and organic-rich sediments (Svensen et al., 2004; 2007; 2009a).

There is thus no shortage of 'kill mechanisms' associated with large-scale volcanism (and indeed large meteorite or cometary impacts), but evidence for impacts at the time of most mass extinction events is unconvincing (see review by Racki, 2012). Many mass extinction events and several oceanic anoxic events and hyperthermals, on the other hand, coincide with flood basalt eruptions. Given the geologically short duration of most flood basalt events, the likelihood of this being 'pure chance' is very small (e.g., Rampino \& Stothers, 1988; Stothers, 1993; Courtillot, 1994; Wignall, 2001; Courtillot \& McLinton, 2002; White \& Saunders, 2005; Bond and Wignall, 2014). It remains unclear, though, why some LIPs (e.g, Paraná-Etendeka) do not cause mass extinctions, and why there is apparently such a poor correlation between volume of LIP and the severity of the mass extinction (Wignall 2001; Ganino \& Arndt, 2009; Bond and Wignall, 2014), although this is not the case for the two systems reviewed here.

This review focusses on the relationships between two large igneous provinces and their associated environmental catastrophes. The North Atlantic Igneous Province (NAIP) developed during the late Palaeocene and early Eocene and is contemporaneous with the Palaeocene-Eocene Thermal Maximum (PETM) (Storey, Duncan \& Swisher, 
2007), a major hyperthermal which is characterised by large and rapid shifts in global temperature and the carbon cycle, and accompanied by a significant mass extinction of benthic formaninfera. The Siberian Traps erupted around the time of the PermoTriassic (PTr) boundary and were synchronous (Renne \& Basu, 1991; Campbell et al., 1992; Reichow et al., 2009) with the end-Permian mass extinction (EPME), the largest known, and also with a large and global change in the global carbon cycle and temperature. Thus the two systems show strong similarities: contemporaneous, largevolume basaltic volcanism and a mass extinction, and they both occurred during periods when the Earth was at least in warm-house conditions, with no permanent/major polar ice caps. Both systems show significant and rapid-onset changes to the ESCC. Global warming during both the PETM and EPME is clearly documented by oxygen isotope studies.. Both volcanic provinces erupted at high latitude. Both the PETM and EPME are well documented by high-precision radiometric dating.

There are, however, some important differences. The NAIP is smaller (at least in terms of area), by up to a factor of 2 , than the Siberian Traps. Whist the Siberian Traps are wholly continent-based, the NAIP was initially continental and but later developed into an oceanic rift system. The extinction during the PETM, whilst significant, affected only benthic fauna, whereas the EPME was the largest known, exterminating $>50 \%$ of genera, in both marine and terrestrial environments. Whilst both events saw extensive marine acidification, with a well-documented shallowing of the lysocline during the PETM (Zachos et al., 2005), the EPME also saw development of major marine anoxia and euxinia that lapped onto the continental shelves and may even have reached the surface (Wignall \& Twitchett, 1996; Kump, Pavlov \& Arthur, 2005). Anoxia during the PETM appears to have been much more limited in extent and intensity (Dickson, Cohen \& Coe, 
2012; Pälicke, Delaney \& Zachos, 2014), although low oxygen levels in oceanic bottom waters may have been the cause of the extinction of benthic foraminifera (Thomas, 1989).

Can we determine the processes that were responsible for the similarities and differences between these two sets of major events? Recent high-precision age dates for both igneous provinces and their contemporaneous surface environment allow a detailed evaluation of the chronology and causes leading up to, and beyond, the two global catastrophes. Three important inputs are required to model any impact of LIPs on the Earth's climate system: (i) the total mass (ii) and type of volatiles that are released, and (iii) the rate at which they are released. To determine these accurately, we need to know both the volume and age profile of the magmatism, the volatile content of the magmas, and the potential volatile content of any adjacent rocks that may be heated by intruded magmas. These parameters are still poorly constrained for most LIPs, including the North Atlantic and Siberian provinces, but arguably they are better known for the NAIP-PETM system than any other.

\section{1) The North Atlantic Igneous Province (NAIP) and the Palaeocene-Eocene Thermal Maximum (PETM)}

The NAIP and Siberian Traps share many features. At the surface, basalt predominates; rhyolite is rare, although the occurrence of silicic intrusives in both provinces suggests that silicic volcanic rocks may have been more abundant, but have since been removed by erosion. Both provinces have abundant basaltic pyroclastic deposits towards the bases of the lava piles, indicating early phreatomagmatic activity (Ross et al., 2005), and both provinces have widespread sill complexes (Thomson, 2004; Ivanov et al., 2009; Svensen et al., 2009a). 
That the Siberian Traps extend over a wider area - approximately twice the size of the N Atlantic Province - is evident from Figure 1, where the two provinces are drawn to the same scale. That these areas are crudely delineated is also indisputable - it is not known, for example, how far the Siberian province extends to the north beneath the Kara Sea, nor how much of the NAIP is located beneath the Greenland icecap - but there is a more fundamental issue that is very difficult to address, namely the continuity of outcrops - were the gaps between far-flung outcrops always there, or were the volcanic rocks removed by erosion? (Similar issues exist for other LIPs, particularly the Central Atlantic Magmatic Province, which has been associated with the end-Triassic mass extinction.) Despite these uncertainties, several estimates of the volumes of the two provinces exist.

The NAIP has two main phases of volcanism (White \& McKenzie, 1989; Saunders et al., 1997): an initial phase of pre-break-up continent-based flood basalt volcanism at $\sim 61$ Ma during Chron 26 and, $\sim 4$ million years later, a second, far more voluminous phase of activity associated with the breakup of the northeast Atlantic during Chron $24 \mathrm{r}$ (beginning $\sim 56.5 \mathrm{Ma}$ ). The two phases of activity are recorded not only in the lava piles, but also by ash layers in nearby basins such as the North Sea (Knox \& Morton, 1988). Remnants of the Phase 1 activity are found at very widespread and separate localities (Baffin Island, West Greenland, parts of East Greenland, the lower part of the Faroes lava pile, and the Hebridean province) - a pre-drift distance of over $2000 \mathrm{~km}$ - but as mentioned above it is unclear whether the magmatism covered the entire region. Volume estimates are therefore tentative, but are likely to be not less than $50,000 \mathrm{~km}^{3}$ (Dickin, 1988) and may well be as much as $150,000 \mathrm{~km}^{3}$, depending on whether there are significant volumes of basalt beneath the Greenland ice sheet, and on the volume of 
the oldest flows along the SE Greenland margin; the oldest flows drilled at Site 917, ODP Leg 152 are $~ 60$ Ma old (Sinton, Hitchen \& Duncan, 1998). The Phase 1 activity appears therefore to have produced a similar volume of lavas as the Miocene Columbia River Basalt Province $\left(175,000 \mathrm{~km}^{3}\right.$ : Tolan et al., 1989).

Phase 2 activity was, however, much more voluminous. Rifting and separation of Greenland from the Eurasian plate during early Chron 24 time ( $~ 56 \mathrm{Ma})$ created two conjugate rifted margins about 2,500 km long, and enabled extensive melting of the mantle. These margins are characterised by voluminous seaward dipping reflectors thick sequences of basalts and less abundant rhyolite - and complementary deep crustal intrusive bodies. It also led to the formation of the bulk of the East Greenland Scoresby Sund basalts $\left(\sim 230,000 \mathrm{~km}^{3}\right.$ : Larsen, Watt \& Watt, 1989) and the upper part of the Faroes basalt province. The volume of the lavas is difficult to estimate because their thickness is poorly constrained and because it is unclear how much has been lost through erosion. Eldholm \& Grue (1994) suggest a figure of $1.8 \times 10^{6} \mathrm{~km}^{3}$ of extrusives (including the Scoresby Sund and Faroes sequences), and a total volume of all igneous material (igneous crust senso lato associated with the continent break-up) of $\sim 6.6 \times 10^{6}$ $\mathrm{km}^{3}$, which is within the range of 5 to $10 \times 10^{6} \mathrm{~km}^{3}$ suggested by White et al. (1987).

The effects of continent breakup on melt generation can be seen in the composition of the lavas. Figure 2 shows plots of Sm/Yb for composite sections from the SE Greenland margin and Noril'sk in Siberia. This ratio gives an indication of the average depth of melting; $\mathrm{Yb}$ is retained by garnet in the mantle source, resulting in a higher $\mathrm{Sm} / \mathrm{Yb}$ ratio if the average depth of melting is higher (caused, for example, by a thick lithospheric lid). As the lithosphere thinned, by stretching or delamination, the average depth of melting was reduced and the extent of melting increased, reducing the garnet effect and 
causing $\mathrm{Sm} / \mathrm{Yb}$ to decrease. This is precisely what is seen in these two geochemical profiles, and as reported by (Fram \& Lesher, 1993, 1997; Fram et al., 1998). As the extent of melting increases, the volume of the melt increases (along with the volume of magmatic volatiles). As a corollary to this, the extent of crustal contamination also shows a marked decrease as the magmatism migrates from continent- to ocean- based (e.g., Saunders et al., 1997), and this will have affected the volume and composition of any volatiles released by the activity.

The likely initiator for the NAIP magmatism was the arrival at the base of the Greenland lithosphere of the proto-Iceland plume at about 61 Ma (Richards, Duncan \& Courtillot, 1989; Larsen, Yuen \& Storey, 1999). This initially caused the relatively small-volume continental flood basalt magmatism and minor uplift (e.g., Saunders et al., 2007). After a short hiatus, plate rupture allowed extensive shallow, decompression melting of the hot plume mantle, voluminous melt generation and greater uplift linked to development of the volcanic rifted margins (Eldholm \& Grue, 1994; Saunders et al., 1997, 2007). Most of the eruptions were subaerial or shallow water - hence assisting the release of volatiles into the atmosphere - along the volcanic rifted margin, but as the margins migrated from the epicentre of the plume (and as the plume's sphere of influence effectively shrank to the vicinity of the Greenland-Faroes Ridge), they became submarine, and atmospheric emissions would have been reduced. Along the GreenlandFaroes Ridge the eruptions were likely to have persisted as mostly subaerial, because of the dynamic uplift above the mantle plume. In short, the combination of rifting and rapid decompression of plume mantle created the large melt volumes, which in turn triggered the environmental impact on the late Palaeocene climate (Eldholm \& Thomas, 1993). 


\section{2.a. The Palaeocene-Eocene Thermal Maximum}

The PETM is a rapid-onset, short-duration, hyperthermal event with pronounced negative oxygen and carbon isotope isotopic excursions (OIE and CIE) (Kennett \& Stott, 1991); a decrease in carbonate productivity associated with shallowing of the carbonate compensation depth and an increase in ocean surface acidification (Zachos et al., 2005; Penman et al., 2014); a major extinction of benthic foraminfera (Thomas, 1989; Thomas \& Shackleton, 1996); marine anoxia and/or dysoxia (Dickson, Cohen \& Coe, 2012;

Dickson et al., 2014) and a major perturbation of global weathering patterns (Ravizza et al., 2001; Wieczorek et al., 2013). It is one of the most studied of the Cenozoic hyperthermals (see, for example, the review by Cohen, Coe \& Kemp, 2007), with over 40 high-resolution deep-sea core sets from ocean drilling, abundant terrestrial sections, and good calibration through astronomical cyclicity (Westerhold, Roehl \& Laskar, 2012). That the Earth's carbon cycle underwent a major perturbation at this time is indicated by the $\sim 2$ to $4 \%$ o decrease of $\delta^{13} \mathrm{C}$ preserved in marine carbonates and fossils over a period of a few thousand years or less, and that lasted for approximately $170 \mathrm{ka}$ (e.g., Rohl et al., 2007). This has led to the suggestion that the cause of the PETM and its associated effects was the rapid injection of a large masse of isotopically light carbon such as methane hydrate - into the ocean-atmosphere system (e.g., Dickens et al., 1995).

Ocean Drilling Program Site 690 from the Weddell Sea is one of several high-resolution sequences that have provided a detailed section across the PETM, and which illustrates the typical profiles of the carbon and oxygen isotopic excursions (Bains, Corfield \& Norris, 1999) (Figure 3). On a broad timescale, the PETM is superimposed on a much longer wavelength variation in carbon and oxygen isotopes $\left(a \delta^{13} \mathrm{C}\right.$ change of about -0.5 $\%$ per my; $\Delta \mathrm{T}$ of about $+0.5^{\circ} \mathrm{C}$ per Ma) that is the development of the Early Eocene 
Climatic Optimum at $\sim 53 \mathrm{Ma}$ (Figure 3), and which arguably began at $\sim 57 \mathrm{Ma}$. At about 55.5 Ma (see below), $\delta^{13} \mathrm{C}$ decreased rapidly, by $\sim 2.5 \%$ at Site 690 , over a timescale of less than a few thousand years, although the minimum duration of this decrease is unconstrained. High-resolution core studies suggest that this initial, rapid, decrease may have occurred over an 'instantaneous' period of time (Wright \& Schaller, 2013), and Rohl et al. (2007) suggest a timescale of <1 ka. Chen et al. (2014), however, from their high-resolution study of an expanded PETM section in central China, conclude that the interval of rapid decline of $\delta^{13} \mathrm{C}$ may be considerably longer. $\delta^{13} \mathrm{C}$ then flatlines for $\sim 80 \mathrm{ka}$, before initially recovering rapidly by $\sim 1 \%$, and then increasing more slowly to intersect the projected pre-CIE curve. The total duration of the PETM is estimated to be $170 \mathrm{ka}$, based on astronomical cyclicity (Rohl et al., 2007), and depending on the positioning of the end of the CIE.

In addition to the CIE, the onset of the PETM is marked by a large oxygen isotope excursion that indicates a global surface warming of between 4 and $7^{\circ} \mathrm{C}$ (Kennett \& Stott, 1991; Bains, Corfield \& Norris, 1999; Jones et al., 2013). The increase in highlatitude sea-surface temperatures was higher $\left(8-10^{\circ} \mathrm{C}\right)$ than their tropical equivalents (4-5 $\left.{ }^{\circ} \mathrm{C}\right)$ (Zachos et al., 2003). The surface temperature increase migrated to progressively deeper waters, with bottom water temperatures increasing by as much as $5^{\circ} \mathrm{C}$ (Zachos et al., 2003). In addition to the downward migration of the thermal pulse and CIE (Thomas et al., 2002), there was also a top-down progression of marine acidification (Zachos et al., 2005), a progressive increase in ocean stratification and a strengthening nutricline (Bralower et al., 2014a,b), and suboxic conditions (Pälicke, Delaney \& Zachos, 2014) leading to the benthic extinction in the warmer deep waters 
(Thomas, 1989). Sea levels also rose, consistent with thermal expansion of the ocean (e.g., Handley, Crouch \& Pancost, 2011).

The CIE, OIE, ocean acidification and benthic foraminifera extinction appear to coincide in many PETM sections (Katz et al., 1999). However, Sluijs et al. (2007) argue that surface-ocean warming, by perhaps as much as $4^{\circ} \mathrm{C}$, began before the CIE and acidification events that mark the onset of the PETM. They base their argument on the acme occurrence of the dinoflagellate cyst Apectodinium, and the palaeothermometer $\mathrm{TEX}_{86}$, in New Jersey margin sediments that were deposited up to $\sim 3$ ka before the main CIE that marks the onset of the PETM. The acme of Apectodinium also occurs in Pacific and North Sea sections, suggesting that this precursor warming is global in extent. Lacustrine sediments from the Nanyang Basin, central China provide a high-resolution dataset through the CIE, preserved in both organic material and micritic carbonate. Not only does the record indicate that the CIE was developing slowly over several ka prior to the main PETM event, but also that the sediments also show a precursor rise $\left(\sim 4^{\circ} \mathrm{C}\right)$ in palaeo-air temperatures based on organic molecules from derived soil material (Chen et al., 2014). Thomas et al. (2002) also report evidence for a brief period of warming prior to the CIE of the PETM, although the oxygen isotope data for high-latitude Site 690 shows a precursor $4^{\circ} \mathrm{C}$ temperature decrease (Bains, Corfield \& Norris, 1999).

\section{2.b. Correlation between the PETM and NAIP}

Astronomically-calibrated cyclostratigraphy, using new orbital solutions, indicates an absolute age for the onset of the PETM (三 Palaeocene-Eocene boundary) of $55.530 \pm$ 0.05 Ma (Westerhold, Roehl \& Laskar, 2012) (Figure 4). Can this age be verified by radiometric dating? Some PETM sections contain dateable ash layers, but these tend to overlie the onset of the P-E boundary rather than bracket it, and any radiometric dates 
$\left(\mathrm{U}-\mathrm{Pb}\right.$ or $\left.{ }^{40} \mathrm{Ar}-{ }^{39} \mathrm{Ar}\right)$ on the tuffs have to be extrapolated to the boundary using cyclostratigraphy or estimations of sedimentation rates, with inherent errors. A weighted mean of the five youngest zircons from an ash layer in the Longyearbyen section, Spitsbergen, has yielded a U-Pb age of $55.785 \pm 0.034 \mathrm{Ma}$ (Charles et al., 2011). The ash layer is $\sim 11 \mathrm{~m}$ above the base of the PETM, so the age has to be increased by between 40 and 80 ka to determine the age of the onset of the PETM. There is thus a significant difference of $\sim 30$-250 ka between the younger astronomically-tuned age and the extrapolated U-Pb age for the PETM, which Westerhold, Roehl \& Laskar (2012) attribute to ageing of the zircons in magma chambers prior to eruption.

${ }^{40} \mathrm{Ar}-{ }^{39} \mathrm{Ar}$ dating of sanidines has also been used to constrain the age of the P-E boundary. Ash Bed -17 is one of several prominent marker horizons in the North Atlantic region and is again situated above the onset of the PETM. Storey, Duncan \& Swisher (2007) obtained an average sanidine fusion age of 55.12 \pm 0.12 Ma for Ash -17 (with a small cluster of possibly xenocrystic ages of about $56 \mathrm{Ma}$ ). The astronomically calibrated age for Ash -17 is, however, significantly younger at $54.850 \pm 0.05 \mathrm{Ma}$, and 680 k.y. younger than the astronomically determined value for the PETM (Westerhold, Roehl \& Laskar, 2012).

Sanidine offers a high-precision dating technique but, because the Ar-Ar method requires calibration using a reference standard (usually Fish Canyon Tuff sanidine, or FCs), and because there is some uncertainty in the potassium decay constant, the errors are inherently greater than the U-Pb method, and accuracy is very reliant on the value of FCs that is used. In the study by Storey et al. (2007), the data were referenced to FCs 28.02 Ma, but recently FCs has been revised to 28.201 Ma (Kuiper et al., 2008), which increases the ${ }^{40} \mathrm{Ar}-{ }^{39} \mathrm{Ar}$ age of Ash Bed -17 to $55.473 \pm 0.12 \mathrm{Ma}$, and thus increases the 
discrepancy with the astronomical age. Westerhold, Roehl \& Laskar (2012) argue that the value for FCs should be reduced to $27.89 \mathrm{Ma}$, which is within error of the value of $28.02 \pm 0.28$ Ma determined by Renne et al. (1998). Using FCs of 27.89 decreases the ${ }^{40} \mathrm{Ar}-{ }^{39} \mathrm{Ar}$ age of Ash -17 to $54.866 \pm 0.12 \mathrm{Ma}$. This, however, increases the discrepancy between the $\mathrm{Ar}-\mathrm{Ar}$ and $\mathrm{U}-\mathrm{Pb}$ dating methods, an issue which grows the further back in time (e.g, to the PTr boundary).

Given that the U-Pb and ${ }^{40} \mathrm{Ar} /{ }^{39} \mathrm{Ar}$ ages for the PETM are both older than the astronomical age does beg the question as to whether the astronomical age for the onset of the PETM is too young. Solutions for the astronomical cycles become increasingly complex in older sequences because of the inherent chaos in the orbital solutions, so this is not an unreasonable suggestion.

Notwithstanding these discrepancies in the absolute age of the P-E boundary, the radiometric dates allow us to correlate the P-E boundary with the magmatism of the NAIP (Figure 4). Ash Bed -17 is petrologically similar to a tuff in the Skrænterne Formation, the uppermost part of the thick pile of Paleocene basalts in east Greenland. The ${ }^{40} \mathrm{Ar}-{ }^{39} \mathrm{Ar}$ ages of Ash -17 and the Skrænterne tuff are indistinguishable (both are 55.12 Ma using FCs of 28.02 Ma), and thus provide an important 'tie' between the PETM-bearing sedimentary successions and the NAIP activity in Greenland (Storey, Duncan \& Swisher, 2007). Furthermore, ${ }^{40} \mathrm{Ar}-{ }^{39} \mathrm{Ar}$ ages on the voluminous, underlying parts of the East Greenland flood basalts bracket the activity between $56.1 \pm 0.4 \mathrm{Ma}$ (Milne Land Formation) and 55.2 \pm 0.4 Ma (Romer Fjord Fm) (Storey, Duncan \& Tegner, 2007) showing that the volcanic activity overlapped with the PETM.

The Skaergaard intrusion in East Greenland intrudes the lower part of the flood basalt lava pile and, it is argued, was crystallising and cooling whilst the bulk of the lava pile 
was emplaced above it, a period that may have been at least as short as 300,000 years (Larsen \& Tegner, 2006). Wotzlaw et al. (2012), using zircon U-Pb ages, estimate that the intrusion emplacement age was $\sim 56.02 \mathrm{Ma}$, and that the minimum age for the flood basalt volcanism in East Greenland was $55.960 \pm 0.064 \mathrm{Ma}$, which again coincides with the age of the onset of the PETM given by Charles et al. (2011). Dolerite sills from the Vøring Basin, Norway, contain zircons with ages of $55.6 \pm 0.3$ and $56.3 \pm 0.4 \mathrm{Ma}$ (Svensen, Planke \& Corfu, 2010).

\section{The Siberian Traps and the End-Permian Mass Extinction (EPME)}

The Siberian Traps also probably owe their origin to a mantle plume (see reviews by: Sharma, 1997; Saunders et al., 2005; Sobolev et al., 2011). The bulk of the exposed lavas and pyroclastic deposits are located on the Siberian Craton around Noril'sk, to the east in Meimecha-Kutoy, and to the southeast in the Tunguska Basin (Figure 1). The Meimecha suites are unusual alkali- and magnesium-rich lavas and intrusives, but the majority of the lavas elsewhere are tholeiitic and alkalic basalts (Sharma, 1997). Extensive sill complexes are found in the underlying sedimentary basins, and these basins host substantial deposits of evaporate and coal. The sills created a large number of explosion craters that may have been important gas release vents during the EPME (Svensen et al., 2009a).

Outliers of Siberian Trap activity are found in the northern Urals around Vorkuta, in the Kuzbass, in Taimyr in the Russian arctic and in the southern Urals around Chelyabinsk, although the latter sub-province is probably slightly younger than the main province (Reichow et al., 2009). However, the main part of the Siberian province appears to reside beneath the West Siberian Basin, which has major N-S rifts and has been considered a failed ocean basin. The exact thickness, distribution and volume of the 
igneous rocks that floor the basin are unknown, but sequences over $1 \mathrm{~km}$ thick have been drilled in parts of the basin (Reichow et al., 2002; Saunders et al., 2005).

The total volume of the volcanic sequences associated with the Siberian province is poorly constrained, for the reasons given above. Saunders \& Reichow (2009) suggest a 'working estimate' of $3 \times 10^{6} \mathrm{~km}^{3}$, plus or minus $1 \times 10^{6} \mathrm{~km}^{3}$. The total volume of the igneous rocks (including lavas, intrusives that ponded within the crust, and cumulates associated with magmatic differentiation) would substantially increase these figures. The bulk of the volcanic rocks are evolved, with Mg numbers $(\mathrm{Mg} / \mathrm{Mg}+\mathrm{Fe})$ less than 0.6 (e.g., Sharma, 1997) so, unless the primary melts had unusually low Mg numbers, substantial volumes of cumulate must exist within the crust. If, as a crude approximation, we assume that the ratio of extrusive/total volume is the same as the NAIP (i.e., $1.8 \times 10^{6} \mathrm{~km}^{3} / 6.6 \times 10^{6} \mathrm{~km}^{3}=0.27$ : Eldholm \& Grue, 1994), then the total volume for the Siberian province would be $\sim 11 \times 10^{6} \mathrm{~km}^{3}$, assuming an extrusive volume of $3 \times 10^{6} \mathrm{~km}^{3}$ (see Section 4). This is about a third of the estimated volume of the Ontong Java Plateau (Gladczenko, Coffin \& Eldholm, 1997).

The role of a mantle plume in the formation of the Siberian Province is contentious, primarily because, unlike the NAIP and Iceland, there is no obvious modern-day descendant hotspot (although some workers have suggested that Iceland hotspot could fill this role: Smirnov \& Tarduno, 2010). Furthermore, the Siberian Province does not show clear evidence of surface uplift (Czamanske et al., 1998) that would be expected from the emplacement of a hot start-up plume (Campbell \& Griffiths, 1990). Sobolev et al. (2011), however, have proposed that the plume may have contained a significant proportion of dense eclogite that reduced the dynamic uplift (see also Cordery, Davies \& Campbell, 1997), and that the plume also stripped the base of the lithosphere, 
effectively making space for it to ascend and decompress, a form of delamination also espoused by Elkins-Tanton (2007).

Like the basalt sequences in the NAIP, the Siberian Traps also show evidence of broad shallowing and decompression of the melt zone in the mantle, in response to either rifting and extension (Saunders et al., 2005), delamination (Elkins-Tanton, 2007), or lithosphere erosion (Sobolev et al., 2011). Figure 2 includes variation of Sm/Yb through the Noril'sk succession. Several of the formations are strongly contaminated by continental crust, but the $\mathrm{Sm} / \mathrm{Yb}$ relationships are preserved. Overall, the $\mathrm{Sm} / \mathrm{Yb}$ values in Noril'sk are higher than those for the NAIP sequence, which is consistent with the thicker lithosphere beneath the Noril'sk region, and the lack of development of an ocean basin in that area. However, the data in Figure 2 indicate that the basalts melts were probably not generated below the thick Siberian Craton, a region of Archaean lithosphere with a present-day thermal thickness in excess of $300 \mathrm{~km}$ (Artemieva \& Mooney, 2001). Rather, they were likely to have formed in the rifted basins to the west of the craton, and flowed eastwards onto the craton. This would entail uplift, possibly plume-assisted, of the lithosphere beneath the West Siberian Basin (e.g., Saunders et al., 2005). Any record of this syn-volcanic uplift is, unfortunately, now buried beneath the thick sedimentary fill.

\section{3.a. The End-Permian Mass Extinction (EPME)}

The mass extinction that occurred near the end of the Permian was the most severe that the Earth has known, destroying as much as 96\% of marine species (Raup, 1979; Benton, 2003; Erwin, 2005). It particularly affected benthic fauna, possibly through immersion in dysoxic, anoxic or even euxinic seawater, but over two thirds of land- 
based reptile and amphibian families and a substantial fraction of insects and land plants were also lost (Wignall and Twitchett, 1996).

Permo-Triassic boundary sections in southern China - including the GSSP at Meishan contain numerous zircon and sanidine bearing volcanic ash layers derived from local contemporaneous silicic, explosive eruptions. These ash layers are located both above and below the main event horizons, enabling precise bracketing of the events (Figure 5). Five of these ash layers have yielded a high-precision $\mathrm{U}-\mathrm{Pb}$ timeline for the culmination of the mass extinction event recorded in the P-Tr global boundary stratotype section and point at Meishan. These have recently enabled Shen et al. (2011), Burgess, Bowring \& Shen (2014) and Wang et al. (2014) to place important constraints on the onset and duration of the CIE and the mass extinction. The main extinction event recorded at Meishan began just below Bed 25 (251.941 $\pm 0.037 \mathrm{Ma})$ and was complete by Bed 28 (251.880 $\pm 0.031 \mathrm{Ma})$, an interval estimated to be $61 \pm 48 \mathrm{ka}$ (Burgess, Bowring \& Shen, 2014). This is considered to be a maximum duration, because the Meishan section at this level is condensed.

Wang et al. (2014) compiled data on 1450 species from 18 sections from south China and northern Gondwana, and integrated these with the radiometric data of Shen et al. (2011). They observe an abrupt extinction of $62 \%$ of species over the $61 \pm 48$ ka interval between Beds 25 and 28. Song et al. (2013), however, report two pulses of extinction, the first in the latest Permian at Bed 25, and the second in the lower Triassic at Bed 28. This suggests that rather than a prolonged period of crisis, there were at least two extinction pulses - perhaps with fundamentally different environmental causes between which were brief periods of recovery. 
Wang et al. (2014) also suggest that environmental conditions were deteriorating from 1.2 Ma. before the sudden extinction. The authors point out that this requires further testing, but it is also suggested by Cao et al. (2009), who observe evidence of major changes in planktic ecology, specifically the radiolarians, well before the main extinction horizon.

There is a substantial volume of literature dealing with the carbon isotope excursions at the end of the Permian and in the Early Triassic. Korte \& Kozur (2010), for example, list over 120 Permo-Triassic sections and cores where the carbon isotope profile has been described, many by more than one study ( $\sim 20$ for the Meishan GSSP alone). Whilst most are marine, the list also includes 28 non-marine sections. There are significant variations in the magnitude and even the stratigraphic position of the anomalies, but a broad consensus has emerged about the general shape of the CIE (Figure 5) (Retallack \& Krull, 2006; Korte \& Kozur, 2010).

Before the onset of the CIE, Permian Palaeotethyan marine carbonate typically gives values of $\delta^{13} \mathrm{C}$ of between +3.5 and $+4 \%$. The rapid decline to $-4 \%$ (Cao et al., 2009) and subsequent recovery has a duration of between 2.1 and $18.8 \mathrm{ka}$, fluctuates by 1-2\%o for the succeeding $\sim 0.5 \mathrm{Ma}$, and then flatlines for $63 \pm 89 \mathrm{ka}$ (Burgess, Bowring \& Shen, 2014). On a longer timescale, $\delta^{13} \mathrm{C}_{\text {carbonate }}$ oscillates dramatically, by more than $11 \%$, throughout the Early Triassic, before stabilising at 2\%o in the lower part of the Middle Triassic (Payne et al., 2004; Payne and Kump, 2007) (Figure 5). The magnitude of the negative CIE preserved in Beds 24 and 25 at Meishan is of the order of 7 to $8 \%$. This compares with average values for the end-Permian CIE in marine and non-marine carbonate of $-4.1 \pm 1.6 \%$ o $(n=22)$ and $-10.4 \pm 2.4 \%$ o $(n=3)$, respectively; the average $\delta^{13} \mathrm{C}$ excursion in marine organic material is $-6.5 \pm 3.6 \%$ o $(n=14)$ (Retallack \& Krull, 2006). 
At Meishan, the CIE begins in Bed 23, before the main mass extinction horizon (Figure 5). In other areas, however, the opposite is true. For example, in their study of the PTr boundary section in Jameson Land, East Greenland, Twitchett et al. (2001) demonstrate that the CIE occurs after the major collapse of the terrestrial and marine ecosystems. Whatever caused the CIE at this locality cannot, therefore, have been responsible for the mass extinction event there. The CIE in the expanded carbonate sequence recovered in the Gartnerkofel-1 core began, like the CIE in Meishan, in the late Permian, but the main excursion occurs above the designated P-Tr boundary and by implication after the mass extinction horizon (Holser et al., 1989). Wignall \& Newton (2003) also argue that the mass extinction began before the CIE in sections from Tibet and British Columbia. Interestingly, the mass extinction appears to occur at different time in these areas; the section in British Columbia, which was located on a deep-water margin to Panthalassa, occurred approximately 0.5 Ma before the extinction in Tibet, located at high palaeolatitude in the partially enclosed Neotethys. Indeed, the Tibetan section shows a marked increase in diversity associated with ocean warming before the delayed extinction in the early Triassic.

Marine anoxia was a prevailing and arguably defining condition around the time of the EPME. The anoxia extended to both high and low palaeolatitudes (Wignall \& Twitchett, 1996), over a range of water depths from the deep Panthalassia Ocean (Isozaki, 1997; Takahashi et al., 2009; Algeo et al., 2011a, b; Shen et al., 2012; Takahashi et al., 2014) to above the storm wave base on the continental shelves (Wignall \& Twitchett, 1996). At times, and especially during the main extinction event, the anoxia developed into euxinia which shoaled into the photic zone (Grice et al., 2005; Riccardi, Arthur \& Kump, 2006; Riccardi et al., 2007) and may even have broached the ocean surface, releasing 
$\mathrm{H}_{2} \mathrm{~S}$ into the atmosphere (Kump, Pavlov \& Arthur, 2005). It is unclear whether photic zone euxinia was restricted to Palaeothethys (Takahashi et al., 2010), or was global in occurrence, although euxinic conditions do appear to have occurred in the deeper parts of Panthalassa (e.g., Takahashi et al., 2014).

The relative timings of the onset the oceanic anoxia, the carbon isotope excursions and the mass extinction event are not consistent across the globe. In sections from the Panthalassic Ocean, for example, euxinia, anoxia or dysoxia began in the late Permian, well before the CIE and mass extinction horizons (Takahashi et al., 2014). In some sections from the margins of Tethys, however, onset of dysoxia is coincident with local benthic extinctions (e.g., Wignall \& Hallam, 1992; Wignall, Morante \& Newton, 1998), and there is the major diachroneity documented by Wignall \& Newton (2003), mentioned earlier. These findings are broadly consistent with anoxia (senso lato) being a persistent and long-lived feature in the major ocean basins, but having a more intermittent effect on the shallower margins or in more enclosed peri-continental basins. In such a system, globally diachronous onset of anoxia - and extinction - may be expected.

The Permo-Triassic superanoxic event has been described as a protracted Strangelove Ocean (Rampino \& Caldeira 2005), where the biological pump between benthic and surface systems completely failed. This, however, is questioned by data published by Meyer et al. (2011), Payne \& Clapham (2012) and Song et al. (2013), where vertical depth gradients in $\delta^{13} \mathrm{C}$ are recorded in some early Triassic sequences.

Brennecka et al. (2011) use variations in ${ }^{235} \mathrm{U} /{ }^{238} \mathrm{U}$ and $\mathrm{Th} / \mathrm{U}$ ratios in marine carbonates to measure ocean redox conditions to demonstrate that the oceanic anoxia coincided with, or only slightly preceded, the main extinction horizon. The advantage of 
this technique is that is provides a record of global ocean conditions rather than a more parochial snapshot. These findings challenge previous suggestions of an extended period of widespread anoxia prior to the end-Permian extinction (e.g., Isozaki, 1997; Cao et al., 2009).

The evidence for a rise in seawater temperature at the time of the EPME was, until recently, less clear than for the PETM (see review by Twitchett, 2007). The global temperature rise from measurements of $\delta^{18} \mathrm{O}$ in marine carbonates (Holser et al., 1989) is of the order of $5-6^{\circ} \mathrm{C}$, although because marine carbonates are susceptible to diagenetic alteration, the data should be treated with caution. However, the temperature rise accords with the climate model of Kidder \& Worsley (2004), and with estimates of tropical sea-surface temperatures based on climatic proxies; e.g. Cui \& Kump (in press). Recently, however, Sun et al. (2012) and Chen et al. (2013) used oxygen isotopes from conodont apatite - arguably more resistant to the effects of diagenesis and recrystallization than carbonates - to indicate that there was a decrease of $\delta^{18} \mathrm{O}$ of as much as $4 \%$ across P-Tr boundary sections in central and southern China, which are equated to a seawater temperature rise of $\sim+15^{\circ} \mathrm{C}$, assuming that the Earth had no major ice caps at that time. The global thermal system continued to oscillate powerfully until the end of the Spathian, but temperatures remained at potentially lethal levels - at least at low latitudes - throughout much of the Early Triassic. Such increases in temperature would account for the contemporaneous sea-level rise, which, through thermal expansion of seawater alone, would be of the order of 20 m (Kidder \& Worsley, 2004).

As with the PETM, there is evidence for ocean acidification around the time of the PTr boundary recorded, for example, in carbonate dissolution on the surfaces on shallow- 
water skeletal carbonates (Payne et al., 2007). Evidence is less clear-cut, however, than for the PETM (Hönisch et al., 2012). Fraiser \& Bottjer (2007) and Payne et al. (2010) argue that the acidification is driven by an atmospheric increase in $\mathrm{CO}_{2}$, similar to the events at the PETM, as oppose to (for example) the development of a strongly stratified (Strangelove) ocean with a calcium carbonate-undersaturated lower layer.

\section{3.b. Correlation between the Siberian Traps and the EPME}

There is a lack of high-precision U-Pb dates from the Siberian Traps and associated intrusives. A sill from the Nepa region gives a $\mathrm{U}-\mathrm{Pb}$ zircon age of $252.0 \pm 0.4 \mathrm{Ma}$ (Svensen et al., 2009a), and a gabbro from Noril'sk an age of 251.2 \pm 0.3 Ma (Kamo, Czamanske \& Krogh, 1996). Basalts from Meimecha-Kotuy have ages ranging from 250.2 to 251.7 Ma (Kamo et al., 2003), but the relationship between the magmatism at Meimecha and the flood basalts around Norilsk, Tunguska and the West Siberian Basin is poorly constrained. At the 2013 AGU Fall Meeting, Burgess \& Bowring (2013) reported high-precision $\mathrm{U}-\mathrm{Pb}$ dates from Meimecha and Norilsk that '...suggest that intrusive and extrusive magmatism began within analytical uncertainty of the onset of mass extinction, permitting a causal connection with age precision at the $\sim \pm 0.06 \mathrm{Ma}$ level.' The publication and interpretation of these new ages is eagerly awaited.

High precision ${ }^{40} \mathrm{Ar}-{ }^{39} \mathrm{Ar}$ dating of sanidines extracted from the ash layers at the Meishan GSSP give significantly younger ages than the co-existing zircons, a problem only partly alleviated by using the revised value for FCs of 28.20 Ma (and made substantially worse if the FCs value of 27.89 Ma as suggested by Westerhold, Roehl \& Laskar 2012 is used). Beds 25 and 28 that bracket the CIE and the mass extinction horizon give ${ }^{40} \mathrm{Ar}-{ }^{39} \mathrm{Ar}$ ages (corrected to $\mathrm{FCs}$ of $28.201 \mathrm{Ma}$ ) of $251.43 \pm 0.15 \mathrm{Ma}$ and 250.85 土 0.14 Ma, respectively (Renne \& Basu, 1991; Renne et al., 1995; Reichow et al., 
2009). These compare with U-Pb ages of $251.941 \pm 0.037$ and $251.88 \pm 0.031$ Ma for

Beds 25 and 28 (Burgess, Bowring \& Shen, 2014). Not only are the ${ }^{40} \mathrm{Ar}-{ }^{39} \mathrm{Ar}$ ages younger, but the difference in ages between Beds 25 and 28 (580 $210 \mathrm{ka}$ ) is significantly greater than that determined by U-Pb (61 $\pm 48 \mathrm{ka})$. Hopefully this inconsistency will be explained by further work in progress.

Basalts from Noril'sk, Tunguska, Kuznetz Basin, Vorkuta in the northern Urals, Taimyr and the West Siberian Basin have ${ }^{40} \mathrm{Ar}-{ }^{39} \mathrm{Ar}$ ages for plagioclase separates that overlap with the ages of sanidines from ash Beds 25 and 28 at Meishan (e.g., Renne et al., 1995; Reichow et al., 2002, 2009). The errors on these ${ }^{40} \mathrm{Ar}-{ }^{39} \mathrm{Ar}$ plagioclase dates are greater than for sanidines, meaning that it is not possible to resolve the range of magmatic activity to much better than a million years or so using this dating technique. A detailed review of the dating of the Siberian Traps is given by Ivanov et al. (2013) who conclude that the magmatism may have persisted well into the Triassic.

\section{Discussion}

In his book, Hallam (2005) mentions that Alan Charig, of the Natural History Museum, alluded to the fact over 90 'kill mechanisms' have been proposed as causes of the extinction of the dinosaurs. Similarly, a large number of mechanisms have been suggested for the EPME and the PETM. A review of all these is fortunately beyond the remit of this paper. Even if we restrict the discussion to the contributions from volcanism, there is still a bewildering array of kill mechanisms that can be marshalled:

1. Primary mechanisms are where volcanism and its associated products directly impact on the surface environment. These include release of volcanic $\mathrm{CO}_{2}$ (leading to global warming and ocean acidification) and $\mathrm{SO}_{2}$ and ash (global 
cooling) and halogens (Cl, F: potential degradation of the ozone layer). Also included here is the production and release of thermogenic carbon $\left(\mathrm{CH}_{4}, \mathrm{CO}_{2}\right.$, CO), halogens, and organo-halogens by injection of sills into carbonates, evaporate or organic rich sediments, again leading to global warming and possibly ozone depletion.

2. Secondary mechanisms are caused by the primary mechanisms. Thus, warming of oceans (by increasing atmospheric $\mathrm{CO}_{2}$ levels) may trigger breakdown of seafloor and permafrost clathrates, and release of $\mathrm{CO}_{2}$ and $\mathrm{CH}_{4}$. Reduction of the ozone layer may lead to increased penetration of ultraviolet light leading to enhanced mutation rates. Warming of oceans may lead to sluggish thermohaline circulation, and development of ocean anoxia. Increased weathering may lead to an enhanced supply of nutrients to the ocean leading to eutrophication and hypoxia (e.g., Grard et al., 2005).

\section{4.a. Gas Fluxes}

Magmas transport large masses of dissolved gases from the mantle to the surface. In the case of flood basalts, these include $\mathrm{H}_{2} \mathrm{O}$, various carbon and sulphur species, and halogens. The content of the gas in the magma is a function of the composition and conditions of melting of the source, and the nature of any contamination as the magmas travel to the surface. Because magmas may have partly or completely degassed before they vent onto the surface, estimates of the original magmatic volatile content are reliant on direct petrological measurements of undegassed melt inclusions trapped inside phenocrysts (Thordarson et al., 1996; Thordarson \& Self, 2003; Self, Thordarson \& Widdowson, 2005; Self et al., 2006, 2008; Blake et al., 2010; Black et al., 2012), or extrapolation of measurements of gas fluxes at modern vents, or proxy methods using 
relationships between melt composition and predicted un-degassed gas content (calibrated by measurement of un-degassed melt inclusions) (Blake et al., 2010).

Given the number of parameters that can affect volatile content, and the limitations of methods to measure them, it is unsurprising that estimates of gas masses released from flood basalt eruptions vary widely. Furthermore, the limitations on the precise duration pattern of magmatism severely restrict our understanding of the emission rates, a key requirement for determining the impact of volatiles on the ESCC.

Estimates of the masses of $\mathrm{S}, \mathrm{Cl}, \mathrm{F}$ and $\mathrm{C}$ released from the 1783 Laki eruption (Iceland), flows from the Columbia River Basalt Group, Deccan Traps and Siberian Traps are given in Table 1. These estimates take into account the volatile content of the magma from direct analysis of melt inclusions (or, in the case of some $S$ data, from proxy calculations) and the proportion of gas that is degassed on eruption. Despite the wide range of values, it is evident that on the basis of even the most conservative calculations, the mass of $\mathrm{S}, \mathrm{Cl}$ and F released from a province such as the Siberian Traps, NAIP (Table 2) and Deccan is prodigious (Thordarson \& Self, 1996; Self et al., 2006, 2008; Blake et al., 2010; Black et al., 2012). These values may be considerably greater if, for example, thermogenic $\mathrm{S}, \mathrm{Cl}$ and $\mathrm{F}$ is released from the contact aureoles of sills emplaced into evaporate- and carbonate-rich sedimentary rocks (Ganino \& Arndt, 2009; Svensen et al., 2009a,b).

Data for $\mathrm{C}$ output are scarce, because the gas (as $\mathrm{CO}_{2}$ or $\left.\mathrm{CO}\right)$ is released from the melt during the early stages of ascent and decompression and is therefore difficult to determine in erupted units. Saunders \& Reichow (2009) estimate that a $1000 \mathrm{~km}^{3}$ flow of basalt could release $6 \mathrm{GtC}$, assuming a magmatic C content of $9000 \mathrm{ppm}$ and a release efficiency of $90 \%$. This compares with approximately 5 MtC.km- ${ }^{3}$ for Hawaiian basalt 
(McCartney, Huffman \& Tredoux, 1990), and 5.6 to $6.5 \mathrm{MtC} . \mathrm{km}^{-3}$ released from the 1783

Laki magma (Thordarson et al., 1996; Hartley et al., 2014). Again, these outputs may be substantially increased by injection of sills and dykes into organic-rich (e.g., coal, methane hydrate) or carbonate-rich country rocks, releasing $\mathrm{C}$ as $\mathrm{CO}_{2}, \mathrm{CO}$ or $\mathrm{CH}_{4}$ (Svensen et al., 2004, 2009a,b; Retallack \& Jahren, 2008; Aarnes et al., 2010; Ogden \& Sleep, 2012).

Cryptic degassing may also play a role. The larger proportion of a LIP is intrusive rather than extrusive, and if gas can escape from these bodies, it will substantially add to the budget of volatiles. Armstrong McKay et al. (2014) estimate that the total C output from the subaerial lavas of the Columbia River Basalts ranges from 230 to $970 \mathrm{Gt}$, depending on the proportion of degassing and the amount of crustal contamination of the magmas. If the intrusive rocks are included, this increases to between 1470 and $6190 \mathrm{GtC}$. There are large uncertainties in these estimates, because (a) the volume of the intrusives and (b) the fraction of $\mathrm{CO}_{2}$ released from the deeper parts of the system, are both poorly constrained. For example, in the case of the Columbia River Basalt Group, the volume of intrusives may range between 420,000 and 1,335,000 $\mathrm{km}^{3}$, depending on whether the estimates are based on petrological modelling or seismic refraction profiling (Armstrong McKay et al., 2014). A further uncertainty is caused by the possibility of 'double accounting'; in other words, at least some cumulates in the crust may have yielded their carbon to the associated fractionated melts.

For the purpose of this exercise I assume that the original magma contained between 5000 and 9000 ppm C, and that degassing efficiency ranged between 70 and $90 \%$ (Table 2). The ratio used for extrusives to total igneous volume is 3.7 (the estimate for the volcanic rifted margins in the North Atlantic: Eldholm \& Grue, 1994). This value is 
probably conservative. The range of estimated C outputs from the Siberian Traps is from 20,000 Gt (low magma volume) to 88,000 Gt (high volume) and for the NAIP (Phase 2), from 18,000 to 40,000 Gt (Table 2). Note that these figures do not include any additional contribution from thermogenic processes. It is interesting to note that Sobolev et al. (2011) also suggest that high-CO2 mantle plume source components may have released $46000 \mathrm{GtC}$ during Siberian Trap event, so the estimates in Table 2 may not be excessive. The data do show, however, that although there is considerable uncertainty in the masses of volatiles released, the potential upper limits are highly significant in terms of the masses required to cause changes to the ESCC.

It may be argued that volcanic gas cannot, alone, produce the CIEs seen at the PETM and EPME. The measured $\delta^{13} \mathrm{C}$ of volcanic gas and, by implication, the upper mantle is generally no lighter than $-10 \%$, and typically $-5 \%$. This means that to reduce the $\delta^{13} \mathrm{C}$ of the atmosphere-ocean system by, say, $1 \%$ requires a mass of twelve times as much volcanic carbon with a value of $-5 \%$, than methane hydrate with a value of $-60 \%$ o (Figure 6). However, this assumes that the $\delta^{13} \mathrm{C}$ of flood basalts is $\sim-5 \%$. Assumptions about basaltic $\delta^{13} \mathrm{C}$ are based on measurements of mid-ocean ridge basalt, upper mantle material, back arc basins and Hawaii (Des Marais \& Moore, 1984; Mattey et al., 1984), but to my knowledge no information on the $\delta^{13} \mathrm{C}$ value of flood basalts exists. Coltice, Simon \& Lecuyer (2004) note that a 'hidden' reservoir of light carbon likely resides in the deep Earth and, given that the mantle conditions that give rise to flood basalts are unusual, possibly involving deeply-sourced start-up plumes, it is perhaps not unreasonable to suggest that their carbon isotope signature may also be unusual and lower than estimated. Deines (2002) notes that a significant fraction of the carbon in many mantle xenoliths has $\delta^{13} \mathrm{C}$ values as low as $-25 \%$ (see also Hansen, 2006; Dal 
Corso et al., 2012), and Sobolev et al. (2011) have suggested that the Siberian Traps were sourced from plume that contained carbon as light as $-12 \%$.

There is now a well-rehearsed argument that release of large masses (>4000 GtC) of methane hydrate from permafrost and the ocean floor is able to explain the carbon isotope excursions at the PETM and EPME (Dickens et al., 1995; Benton and Twitchett, 2003; Racki and Wignall, 2005; Retallack \& Krull, 2006; Dunkley Jones et al., 2010). Methane hydrates have low $\delta^{13} \mathrm{C}(\sim-60 \%)$ (Kvenvolden, 2002), and they can, in theory, release a large amount of carbon (as methane) rapidly; there is a strong positive feedback. This has been used to explain the magnitude and rapidity of the onset of the CIE (few ka or less), the concomitant CIE on land as well as in the oceans, and the topdown acidification and warming of the oceans (Fraiser \& Bottjer, 2007; Zachos et al., 2010).

We do not know the volume of methane hydrates stored in the end-Palaeocene and endPermian sea beds and permafrost regions; given that both periods were without permanent polar ice caps, and that the seawater temperatures were higher than at present, it is likely that the volumes were less than at the present day (Buffett \& Archer, 2004). Strong arguments have also been raised against there being sufficient hydrate reservoir to produce the required changes in temperature (Zachos et al., 2003; Pagani et al., 2006; Dunkley Jones et al., 2010) and, at least for the end-Permian, it is possible that previous global warming events would have depleted the hydrate reservoir (Majorowicz et al., 2014). It is also unclear how methane hydrate release alone can explains the persistently low $\delta^{13} \mathrm{C}$ 'flatline' ( $\sim 80$ ka for the CIE at the PETM; $63 \pm 89 \mathrm{ka}$ for the CIE at the EPME) unless there is protracted 'bleeding' of methane from the seafloor (Zeebe, 2013). 


\section{4.b. A greater role for volcanic $\mathrm{CO}_{2}$ ?}

The available radiometric dates show that the Siberian Traps are contemporaneous with the EPME, and the NAIP with the PETM, at least within the resolution of the dating methods. This has been consistent theme over the last two decades of research. The dates have also progressively reduced the perceived duration for the onset of both the PETM and EPME (both the mass extinction and the associated isotope and excursions) to the point where at least part of the earth-system collapse is geologically 'instantaneous'. Unfortunately, the dating methods do not as yet provide the resolution to adequately determine the magma and gas fluxes, and the temporal pattern of these.

The Phase 1 activity of the NAIP (61 Ma) does not appear to have affected the ESCC as recorded by oxygen and carbon isotopes (e.g., Figure 3). Although it is tempting to suggest that the steady decrease increase in temperature from about 59 Ma may have been due to $\mathrm{CO}_{2}$ degassing associated with the early NAIP, it would appear that the Phase 1 activity had decreased, and possibly stopped, by this time. The increase in temperature is also accompanied by an increase in $\delta^{13} \mathrm{C}$. At about $57 \mathrm{Ma}$, the $\delta^{13} \mathrm{C}$ begins a long-term decrease that ends at the Early Eocene Climatic Optimum, 51 Ma; the surface temperature continued to rise throughout this period.

For volcanic $\mathrm{CO}_{2}$ to have caused estimated long-term $2^{\circ} \mathrm{C}$ rise in temperature from 57 Ma to the onset of the PETM, a significant long-term increase of atmospheric $\mathrm{CO}_{2}$ would be required. If the climate sensitivity in the Palaeocene was a $4^{\circ} \mathrm{C}$ rise per doubling of atmospheric $\mathrm{CO} 2$, and if the original $\mathrm{CO}_{2}$ content of the atmosphere was $500 \mathrm{ppmv}$, approximately $1000 \mathrm{GtC}$ would need to be added (Pagani et al., 2006). Equilibrium between the atmosphere and the ocean would require this mass to be increased to about $4000 \mathrm{Gt}$. Even if this estimate is incorrect by a factor of two, it is still well within 
the range of the mass of carbon that could have been released by the NAIP (up to 40,000 Gt excluding any input from thermogenic sources), and would be consistent with a decrease of $\delta^{13} \mathrm{C}$ of $1 \%$ if the added carbon had an average $\delta^{13} \mathrm{C}$ value of $-10 \%$.

As the flux of the magmatism and $\mathrm{CO}_{2}$ degassing climaxed with the development of the volcanic rifted margins at about $56 \mathrm{Ma}$, ocean warming may have crossed a threshold and triggered the pulsed breakdown of methane hydrates and caused the PETM and its attendant effects. The average atmospheric and ocean $\delta^{13} \mathrm{C}$ would have decreased sharply but, because both volcanic and hydrate carbon (and possibly organic carbon from devastated terrestrial biomass) would have been injected into the ESCC, the total mass of hydrate released may have been much less than previously suggested. Continued, high flux injection of volcanic $\mathrm{CO}_{2}$ for the succeeding 80 ka may have maintained the persistently low flatline $\delta^{13} \mathrm{C}$ value of the PETM CIE (contra Zeebe, 2013). The rapid recovery at the end of the CIE may in part have been caused by cessation of the high-volume magmatic flux, and not solely due to rapid carbon sequestration in a regenerating biomass (Bowen \& Zachos, 2010).

The impact of $\mathrm{SO}_{2}$ and halogen-bearing compounds in the PETM is unclear. The released masses of these gases was likely to have been large but, because of their short residence times in the atmosphere (for an instantaneous gas injection, this will be $<2$ years in the stratosphere and a few weeks in the troposphere, but their longevity is more a function of the duration of the eruption), their impact was probably ephemeral. However, sustained eruptions (over decades or even centuries in the case of the largest flood basalt flood units) could have triggered ecosystem collapse through short-term cooling and reduction of photosynthesis because of protracted blocking of sunlight by $\mathrm{H}_{2} \mathrm{SO}_{4}$ 
aerosols (Stothers et al., 1986; Rampino, Self \& Stothers, 1988; Stothers, 1993;

Thordarson \& Self, 1996; Self et al., 2005, 2006; Saunders and Reichow, 2009).

Unfortunately we do not know the precise age of the onset of the Siberian Trap magmatism in relation to the EPME, so it is unclear whether volcanically-induced warming occurred in the late Permian prior to the EPME and the associated CIE. There is no evidence that the widespread basaltic volcanism at Norilsk and around Tunguska began significantly before the extinction horizon at Meishan, but the error bars in the available radiometric dates do not provide a definitive statement (e.g., Reichow et al., 2009). Give that widespread and dispersed volcanic activity is recorded in many areas in Siberia, including the deeply-buried West Siberian Basin, it is possible that some of this magmatism occurred significantly prior to the EPME; we simply do not know. The Meishan record shows that the $\delta^{13} \mathrm{C}$ signature began to decline from about Bed 23, a mere few 10's of ka before the major collapse at Bed 25, but prior to that time (Beds 20 to 23 ) the carbon isotope record fluctuated, but by no more than $1 \%$, and with no consistent trend. At the end of the Permian, environmental conditions in at least part of the marine realm appear to have been deteriorating, with evidence of anoxia and photic zone euxinia, perhaps as much a 1 Ma before the EPME (Cao et al., 2009; Wang et al., 2014).

The calculated volumes of basalt and hence $\mathrm{CO}_{2}$ produced by the Siberian Traps were two or three times that of the NAIP and this may be the simplest reason why the EPME was so much more severe than the PETM. This is offset howver by the predicted higher pre-volcanic levels of $\mathrm{CO}_{2}$ in the end-Permian atmosphere (e.g., Kidder \& Worsley, 2004). Release of hydrates may again be responsible for the rapid decline in $\delta^{13} \mathrm{C}$ in the latest Permian but, like the PETM, it is unclear how much hydrate was present in the 
late Permian. Majorowicz et al. (2014) have argued that by this time, most of the hydrates would have been exhausted by previous ocean warming, and Payne et al. (2010) use Ca isotopes to argue that the end-Permian CIE was produced from an injection of carbon with a $\delta^{13} \mathrm{C}$ value heavier than $-28 \%$, and closer to- $15 \%$, i.e., it likely contained a substantial volcanic carbon component.

\section{Concluding Observations}

That there is a causal relationship between large igneous provinces and major perturbations of the ESCC is clear. In many instances the volcanism and attendant degassing triggers such severe disruption to the ocean atmosphere system (e.g., major warming, oceanic anoxia and acidification) that it leads to mass extinction. In the case of the two systems reviewed here the larger LIP, the Siberian Traps, had a much greater impact on the environment than the North Atlantic Igneous Province. This may not have solely been due to size, however. A substantial portion of the NAIP activity occurred at a rifting margin in an 'oceanic' realm, and was relatively uncontaminated by continental crust. This may have reduced the mass and changed the types of volatiles that were emitted. The onset of magmatism in the NAIP - associated with the putative plume impact at $\sim 61 \mathrm{Ma}$ - did not appear to cause any major disruption to the ESCC. Again, this may be because the volumes of this initial magmatism were smaller than the subsequent phase 2 activity accompanying continental break-up.

There is no definitive evidence for either a meteorite or comet as triggers for the PETM or EPME. Bowen et al. (2015) note the pulsed nature of C release during the PETM, which is not consistent with a single cometary impact (Kent et al., 2003). The precursor deterioration of the environment prior to the EPME also suggests that a single impact could not have caused the dramatic changes in the ESCC. 
Whilst flood basalts may provide information on current and future changes to the ESCC, it is confounded by differences in climate forcing. In their study of the effects of palaeogeography on climate throughout the Phanerozoic, Godderis et al. (2014) noted that during the late Permian and through the Triassic, the response to doubling of atmospheric $\mathrm{CO}_{2}$ was much greater than at other times during the Phanerozoic, including the present day.

The main unknowns in both the NAIP-PETM and Siberian Traps-EPME systems are the precise timings and the temporal fluxes of gas release, from the intrusive ('cryptic' and thermogenic) and extrusive activity. 'Average' eruption and gas emission rates, calculated for the maximum possible duration of the provinces (1-2 Ma?), give fluxes that are, superficially, insubstantial (e.g., a total output of 50,000 GtC over 2 Ma gives 25 $\mathrm{MtC} / \mathrm{a}$, a fraction of the current 7 to $8 \mathrm{GtC} / \mathrm{a}$ ). However, if the bulk of either the NAIP or Siberian Traps were erupted over a much shorter time period, as has been demonstrated for the Deccan Traps (Chenet et al., 2007), then the fluxes would be substantially higher, which accords with the pulsed C-release at the time of the PETM reported by Bowen et al. (2015). It almost goes without saying, therefore, that evaluating the eruption histories and gas fluxes of LIPs such as the Siberian Traps and the NAIP should be a high scientific priority.

\section{Acknowledgements}

Paul Wignall and Grzegorz Racki provided helpful reviews. Studies of the Siberian Traps and North Atlantic Igneous Province were supported by the Natural Environment Research Council, UK (NE/C003276/1) and National Science Foundation, USA (EAR 0807585/5710002542).

\section{Declaration of Interest}

As far as I am aware there are no conflicts of interest associated with this research or this publication.

\section{References}


AARNeS, I., SVENSEN, H., CONNOlly, J. A. D. \& PodLADChIKOV, Y. Y. 2010. How contact metamorphism can trigger global climate changes: Modeling gas generation around igneous sills in sedimentary basins. Geochimica et Cosmochimica Acta 74(24), 7179-95.

Algeo, T. J., Chen, Z. Q., Fraiser, M. L. \& TWitchett, R. J. 2011a. Terrestrial-marine teleconnections in the collapse and rebuilding of Early Triassic marine ecosystems. Palaeogeography, Palaeoclimatology, Palaeoecology 308(1-2), 1-11.

Algeo, T. J., KuWAhara, K., SANo, H., BAtes, S., Lyons, T., ElsWick, E., Hinnov, L., Ellwood, B., Moser, J. \& MAYNARD, J. B. 2011b. Spatial variation in sediment fluxes, redox conditions, and productivity in the Permian-Triassic Panthalassic Ocean. Palaeogeography, Palaeoclimatology, Palaeoecology 308(1-2), 65-83.

Alvarez, L. W., Alvarez, W., AsARo, F. \& Michel, H. V. 1980. Extraterrestrial causes for the CretaceousTertiary extinction. Science 208, 1095-108.

Armstrong McKay, D. I., TYRrell, T., WiLSON, P. A. \& Foster, G. L. 2014. Estimating the impact of the cryptic degassing of Large Igneous Provinces: A mid-Miocene case-study. Earth and Planetary Science Letters 403, 254-62.

ARTEMieVA, I. M. \& MOONEY, W. D. 2001. Thermal thickness and evolution of Precambrian lithosphere: a global study. Journal of Geophysical Research 106(B8), 16387-414.

BAINS, S., CORFIELD, R. M. \& NORRIS, R. D. 1999. Mechanisms of Climate Warming at the End of the Paleocene. Science 285(5428), 724-27.

BeCKer, L., Poreda, R. J., Hunt, A. G., BunCH, T. E. \& RAMpino, M. 2001. Impact event at the PermianTriassic boundary: evidence from extraterrestrial noble gases in fullerenes. Science 291, 153033.

BENTON, M. J. 2003. When Life Nearly Died. The Greatest Mass Extinction of all Time. London: Thames and Hudson. $336 \mathrm{pp}$.

BENTON, M. J. \& TWITCHETT, R. J. 2003. How to kill (almost) all life: the end-Permian extinction event. Trends in Ecology \& Evolution 18(7), 358-65.

Black, B. A., Elkins-TANTON, L. T., Rowe, M. C. \& PEATE, I. U. 2012. Magnitude and consequences of volatile release from the Siberian Traps. Earth and Planetary Science Letters 317, 363-73.

BLAKE, S., SelF, S., SHARMA, K. \& SEPHTON, S. 2010. Sulfur release from the Columbia River Basalts and other flood lava eruptions constrained by a model of sulfide saturation. Earth and Planetary Science Letters 299(3-4), 328-38.

BOND, D. P. G. \& WIGNALL, P. B. 2014. Large igneus provinces and mass extinctions: an update. In Volcanism, Impacts, and Mass Extinctions (eds G. Keller and A. C. Kerr), Geological Society of America Special Paper 505, pp. 29-56.

Bowen, G. J., Maibauer, B. J., Kraus, M. J., Rohl, U., Westerhold, T., Steimke, A., Gingerich, P. D., WING, S. L. \& CLYDE, W. C. 2015. Two massive, rapid releases of carbon during the onset of the Palaeocene-Eocene thermal maximum. Nature Geoscience 8(1), 44-7.

BOWEN, G. J. \& ZACHOS, J. C. 2010. Rapid carbon sequestration at the termination of the PalaeoceneEocene Thermal Maximum. Nature Geoscience 3(12), 866-69.

Bralower, T. J., Kelly, D. C., GibBS, S., FARLEY, K., ECCLES, L., LINDEMANN, T. L. \& SMith, G. J. 2014a. Impact of dissolution on the sedimentary record of the Paleocene-Eocene thermal maximum. Earth and Planetary Science Letters 401(0), 70-82.

BRalower, T. J., MeisSner, K. J., AleXANDER, K. \& ThOMAS, D. J. 2014b. The dynamics of global change at the Paleocene-Eocene thermal maximum: A data-model comparison. Geochemistry, Geophysics, Geosystems 15(10), 3830-48.

Brennecka, G. A., Herrmann, A. D., Algeo, T. J. \& Anbar, A. D. 2011. Rapid expansion of oceanic anoxia immediately before the end-Permian mass extinction. Proceedings of the National Academy of Sciences of the United States of America 108(43), 17631-34.

BUFFETT, B. \& ARCHER, D. 2004. Global inventory of methane clathrate: sensitivity to changes in the deep ocean. Earth and Planetary Science Letters 227(3-4), 185-99. 
BURGESS, S. D., BOWRING, S. \& SHEN, S.-Z. 2014. High-precision timeline for Earth's most severe extinction. Proceedings of the National Academy of Sciences 111(9), 3316-21.

CAmpBell, I. A., CZAmAnske, G. K., Fedorenko, V. A., Hill, R. I. \& StepanoV, V. 1992. Synchronism of the Siberian Traps and the Permian-Triassic boundary. Science 258, 1760-63.

CAMPBELL, I. H. \& GRIFFITHS, R. W. 1990. Implications of mantle plume structure for the evolution of flood basalts. Earth and Planetary Science Letters 99, 79-93.

CAO, C. Q., WANG, W. \& JIN, Y. G. 2002. Carbon isotope excursions across the Permian-Triassic boundary in the Meishan section, Zhejiang Province, China. Chinese Science Bulletin 47(13), 1125-29.

CAO, C., LOVE, G. D., HAYS, L. E., WANG, W., SHEN, S. \& SUMmons, R. E. 2009. Biogeochemical evidence for euxinic oceans and ecological disturbance presaging the end-Permian mass extinction event. Earth and Planetary Science Letters 281(3-4), 188-201.

Charles, A. J., Condon, D. J., Harding, I. C., PÄlike, H., Marshall, J. E. A., CUI, Y., Kump, L. \& Croudace, I. W. 2011. Constraints on the numerical age of the Paleocene-Eocene boundary. Geochemistry, Geophysics, Geosystems 12(6), Q0AA17.

CHEN, B., JOACHIMSKI, M. M., SHEN, S.-Z., LAMBeRT, L. L., LAI, X.-L., WANG, X.-D., CHEN, J. \& YUAN, D.-X. 2013. Permian ice volume and palaeoclimate history: Oxygen isotope proxies revisited. Gondwana Research 24(1), 77-89.

Chen, Z., WANG, X., HU, J., YANG, S., ZHU, M., DONG, X., TANG, Z., PENG, P. A. \& DING, Z. 2014. Structure of the carbon isotope excursion in a high-resolution lacustrine Paleocene-Eocene Thermal Maximum record from central China. Earth and Planetary Science Letters 408(0), 331-40.

Chenet, A.-L., Quidelleur, X., FluteAu, F., Courtillot, V. \& BAJPAI, S. 2007. 40K-40Ar dating of the Main Deccan large igneous province: Further evidence of KTB age and short duration. Earth and Planetary Science Letters 263(1-2), 1-15.

Cohen, A. S., COE, A. L. \& KeMP, D. B. 2007. The Late Palaeocene-Early Eocene and Toarcian (Early Jurassic) carbon isotope excursions: a comparison of their timescales, associated environmental changes, causes and consequences. Journal of the Geological Society 164, 1093-108.

COLTICE, N., SimON, L. \& LECUYER, C. 2004. Carbon isotope cycle and mantle structure. Geophysical Research Letters 31(5), 5.

CORDERY, M. J., DAVIES, G. F. \& CAMPBELL, I. H. 1997. Genesis of flood basalts from eclogite-bearing mantle plumes. Journal of Geophysical Research 102(B9), 20179-97.

COURTILLOT, V. 1994. Mass extinctions in the last 300 million years: one impact and seven flood basalts? Israeli Journal of Earth Sciences 43, 255-66.

COURTILLOT, V. \& MCLINTON, J. 2002. Evolutionary Catastrophes: The Science of Mass Extinction. Cambridge: Cambridge University Press.

CUI, Y. \& KUMP, L. R. In press, 2015. Global warming and the end-Permian extinction event: Proxy and modeling perspectives. Earth-Science Reviews (0).

CZAMANSKe, G. K., GureVitch, V., Fedorenko, V. \& Simonov, O. 1998. Demise of the Siberian plume: palaeogeographic and palaeotectonic reconstruction from the prevolcanic and volcanic record, north-central Siberia. International Geology Review 40, 95-115.

Dal Corso, J., Mietto, P., Newton, R. J., Pancost, R. D., Preto, N., Roghi, G. \& Wignall, P. B. 2012. Discovery of a major negative $\delta 13 \mathrm{C}$ spike in the Carnian (Late Triassic) linked to the eruption of Wrangellia flood basalts. Geology 40(1), 79-82.

DEINES, P. 2002. The carbon isotope geochemistry of mantle xenoliths. Earth-Science Reviews 58(34), 247-78.

Des MARAIS, D. J. \& MoORE, J. G. 1984. Carbon and its isotopes in mid-oceanic basaltic glasses. Earth planet. Sci. Lett. 69, 43-57.

DICKENS, G. R., ONEIL, J. R., REA, D. K. \& OWEN, R. M. 1995. Dissociation of Oceanic Methane Hydrate as a Cause of the Carbon-Isotope Excursion at the End of the Paleocene. Paleoceanography 10(6), 965-71. 
DICKIN, A. P. 1988. The North Atlantic Tertiary Province. In Continental Flood Basalts (ed J. D. Macdougall). pp. 111-49. Dordrecht, Netherlands: Kluwer Academic Publishers.

Dickson, A. J., COHEN, A. S. \& COE, A. L. 2012. Seawater oxygenation during the Paleocene-Eocene Thermal Maximum. Geology 40(7), 639-42.

Dickson, A. J., Rees-Owen, R. L., Maerz, C., Coe, A. L., Cohen, A. S., Pancost, R. D., Taylor, K. \& SHCHERBININA, E. 2014. The spread of marine anoxia on the northern Tethys margin during the Paleocene-Eocene Thermal Maximum. Paleoceanography 29(6), 471-88.

DUNKLEY JONES, T., RIDGWELL, A., LUNT, D. J., MASLIN, M. A., SCHMIDT, D. N. \& VALDES, P. J. 2010. A Palaeogene perspective on climate sensitivity and methane hydrate instability. Philosophical Transactions of the Royal Society a-Mathematical Physical and Engineering Sciences 368(1919), 2395-415.

ELDHOLM, O. \& GRUE, K. 1994. North Atlantic volcanic margins: dimensions and production rates. J. Geophys. Res. 99(B2), 2955-68.

ELDHOLM, O. \& THOMAS, E. 1993. Environmental impact of volcanic margin formation. Earth planet. Sci. Letts. 117, 319-29.

ELKINS-TANTON, L. T. 2007. Continental magmatism, volatile recycling, and a heterogeneous mantle caused by lithospheric gravitational instabilities. Journal of Geophysical Research-Solid Earth 112(B3).

ERWIN, D. H. 2005. Extinction: How Life on Earth Nearly Ended 250 Million Years Ago. Princeton and Oxford: Princeton University Press. 296pp.

FRAISER, M. L. \& BOTTJER, D. J. 2007. Elevated atmospheric CO2 and the delayed biotic recovery from the end-Permian mass extinction. Palaeogeography, Palaeoclimatology, Palaeoecology 252(12), 164-75.

FRAM, M. \& LESHER, C. E. 1993. Geochemical constraints on mantle melting during creation of the North Atlantic basin. Nature 363, 712-15.

FRAM, M. S. \& LESHER, C. E. 1997. Generation and polybaric differentiation of East Greenland early Tertiary flood basalts. Journal of Petrology 38(2), 231-75.

FrAM, M. S., LeSHER, C. E. \& VolPE, A. M. 1998. Mantle melting systematics: the transition from continental to oceanic volcanism on the southeast Greenland margin. In Scientific Results, Ocean Drilling Program 152 (eds A. D. Saunders, H. C. Larsen and S. Wise). pp. 373-86. College Station, Texas: Ocean Drilling Program.

GANINO, C. \& ARNDT, N. T. 2009. Climate changes caused by degassing of sediments during the emplacement of large igneous provinces. Geology 37(4), 323-26.

GEIKIE, A. 1903. Textbook of Geology, 4th ed.

GlAdCZENKO, T. P., Coffin, M. F. \& Eldholm, O. 1997. Crustal structure of the Ontong Java Plateau: modelling of new gravity and existing seismic data. Journal of Geophysical Research 102(B10), 22711-29.

Godderis, Y., DonNADIEU, Y., LE HIR, G., LefEBVRE, V. \& NARDIN, E. 2014. The role of palaeogeography in the Phanerozoic history of atmospheric CO2 and climate. Earth-Science Reviews 128, 122-38.

Grard, A., Francols, L. M., DesSert, C. \& GoddéRIS, Y. 2005. Basaltic volcanism and mass extinction at the Permo-Triassic boundary: environmental impact and modeling of the global carbon cycle. Earth and Planetary Science Letters 234, 207-21.

Grice, K., CaO, C. Q., Love, G. D., Bottcher, M. E., TWitchett, R. J., Grosjean, E., Summons, R. E., TURGEON, S. C., DUNNING, W. \& JIN, Y. G. 2005. Photic zone euxinia during the Permian-Triassic superanoxic event. Science 307(5710), 706-09.

Hallam, A. 2005. Catastrophes and Lesser Calamities: The Causes of Mass Extinctions. Oxford: Oxford University Press. 240 pp.

Hallam, A. \& WignalL, P. B. 1997. Mass Extinctions and Their Aftermath. New York, N.Y.: Oxford University Press. 320 pp. 

Palaeoclimatology, Palaeoecology 305(1-4), 185-200.

HANSEN, H. J. 2006. Stable isotopes of carbon from basaltic rocks and their possible relation to atmospheric isotope excursions. Lithos 92(1-2), 105-16.

HARTLEY, M. E., MACLENNAN, J., EdMONDS, M. \& THORDARSON, T. 2014. Reconstructing the deep CO2 degassing behaviour of large basaltic fissure eruptions. Earth and Planetary Science Letters 393, 120-31.

HAWkesworth, C. J., Lightfoot, P. C., Fedorenko, V. A., Blake, S., NAldRett, A. J., Doherty, W. \& GORBACHEV, N. S. 1995. Magma differentiation and mineralisation in the Siberian continental flood basalts. Lithos 34, 61-88.

Holser, W. T., SChÖnlaub, H.-P., Attrep, M., Boeckelmann, K., Klein, P., Magaritiz, M., Orth, C. J., Fenninger, A., Jenny, C., Kralik, M., Mauritsch, H., Pak, E., Schramm, J.-M., Stattegger, K. \& SCHMÖLLER, R. 1989. A unique geochemical record at the Permian-Triassic boundary. Nature 337, 39-44.

ISOZAKI, Y. 1997. Permo-Triassic boundary superanoxia and stratified superocean: records from lost deep sea. Science 276, 235-38.

IVAnov, A. V., He, H., Yan, L., Ryabov, V. V., Shevko, A. Y., Palesskil, S. V. \& Nikolaeva, I. V. 2013. Siberian Traps large igneous province: Evidence for two flood basalt pulses around the Permo-Triassic boundary and in the Middle Triassic, and contemporaneous granitic magmatism. Earth-Science Reviews 122(0), 58-76.

IVANOV, A. V., He, H., YANG, L., NiKolaeva, I. V. \& PALESSKII, S. V. 2009. 40Ar/39Ar dating of intrusive magmatism in the Angara-Taseevskaya syncline and its implication for duration of magmatism of the Siberian traps. Journal of Asian Earth Sciences 35(1), 1-12.

Jones, T. D., LUNT, D. J., SCHMIDT, D. N., RIDGWELL, A., SLUIJS, A., VALDES, P. J. \& MASLIN, M. 2013. Climate model and proxy data constraints on ocean warming across the Paleocene-Eocene Thermal Maximum. Earth-Science Reviews 125, 123-45.

KAmo, S. L., CZAMANSke, G. K. \& KROGH, T. E. 1996. A minimum U-Pb age for Siberian flood-basalt volcanism. Geochimica et Cosmochimica Acta 60(18), 3505-11.

Kamo, S. L., CZAmanske, G. K., Amelin, Y., Fedorenko, A., Davis, D. W. \& Trofimov, V. R. 2003. Rapid eruption of Siberian flood-volcanic rocks and evidence for coincidence with the PermianTriassic boundary and mass extinction at $251 \mathrm{Ma}$. Earth and Planetary Science Letters 214, 7591.

KATZ, M. E., PAK, D. K., DICKENS, G. R. \& MILLER, K. G. 1999. The source and fate of massive carbon input during the latest Paleocene thermal maximum. Science 286, 1531-33.

KENNETT, J. P. \& STOTT, L. D. 1991. Abrupt deep-sea warming, palaeoceanographic changes and benthic extinctions at the end of the Palaeocene. Nature 353(6341), 225-29.

Kent, D. V., CRAMER, B. S., LANCI, L., WANG, D., WRIGHT, J. D. \& VAN DER VOO, R. 2003. A case for a comet impact trigger for the Paleocene/Eocene thermal maximum and carbon isotope excursion. Earth and Planetary Science Letters 211, 13-26.

KIDDER, D. L. \& WORSLEY, T. R. 2004. Causes and consequences of extreme Permo-Triassic warming to globally equable climate and relation to the Permo-Triassic extinction and recovery. Palaeogeography Palaeoclimatology Palaeoecology 203(3-4), 207-37.

KNOX, R. W. \& MORTON, A. C. 1988. The record of early Tertiary N Atlantic volcanism in sediments of the North Sea Basin. In Early Tertiary Volcanism and the Opening of the NE Atlantic (eds A. C. Morton and L. M. Parson). pp. 407-19. Oxford: Geological Society London Special Publication 39.

KORTE, C. \& KOzUR, H. W. 2010. Carbon-isotope stratigraphy across the Permian-Triassic boundary: A review. Journal of Asian Earth Sciences 39(4), 215-35.

KUIPER, K. F., DeINO, A., HILgen, F. J., KRIJgSman, W., RENNE, P. R. \& WIJBRANS, J. R. 2008. Synchronizing rock clocks of Earth history. Science 320(5875), 500-04. 
KUMP, L. R., PAVLOV, A. \& ARTHUR, M. A. 2005. Massive release of hydrogen sulfide to the surface ocean and atmosphere during intervals of oceanic anoxia. Geology 33(5), 397-400.

KVENVOLDEN, K. A. 2002. Methane hydrate in the global organic carbon cycle. Terra Nova 14(5), 30206.

LARSEN, L. M., WATT, W. S. \& WATT, M. 1989. Geology and petrology of the Lower Tertiary plateau basalts of the Scoresby Sund region, East Greenland. Bull. Geol. Surv. Greenland 157, 1-164.

LARSEN, R. B. \& TEGNER, C. 2006. Pressure conditions for the solidification of the Skaergaard intrusion: Eruption of East Greenland flood basalts in less than 300,000 years. Lithos 92(1-2), 181-97.

LARSEN, T. B., YUEN, D. A. \& STOREY, M. 1999. Ultrafast mantle plumes and implications for flood basalt volcanism in the northern Atlantic region. Tectonophysics 311, 31-43.

LAWVER, L. A. \& MüLLER, R. D. 1994. Iceland hotspot track. Geology 22, 311-14.

Lightfoot, P. C., NAlDRett, A. J., GorbaCheV, N. S., DoherTy, W. \& Fedorenko, V. A. 1990. Geochemistry of the Siberian Traps of the Noril'sk area, USSR, with implications for the relative contributions of crust and mantle to flood basalt magmatism. Contrib. Mineral. Petrol. 104, 631-44.

MAJOROWICZ, J., GRASBY, S. E., SAFANDA, J. \& BEAUChAMP, B. 2014. Gas hydrate contribution to Late Permian global warming. Earth and Planetary Science Letters 393(0), 243-53.

MASLIN, M. A. \& THOMAS, E. 2003. Balancing the deglacial global carbon budget: the hydrate factor. Quaternary Science Reviews 22(15-17), 1729-36.

MATTEY, D. P., CARR, R. H., WRIGHT, I. P. \& PILLINGER, C. T. 1984. Carbon isotopes in submarine basalts. Earth planet. Sci. Lett. 70, 196-206.

MCCARTNEY, K., HufFMAN, A. R. \& TREDOUX, M. 1990. A paradigm for endogenous causation of mass extinctions. In Global Catastrophes in Earth History (eds V. L. Sharpton and P. D. Ward), Geological Society of America Special Paper 247, pp 125-38.

MCLEAN, D. M. 1985. Deccan traps mantle degassing in the terminal Cretaceous marine extinctions. Cretaceous Research 6(3), 235-59.

MEYER, K. M., YU, M., JOST, A. B., KELLEY, B. M. \& PAYNE, J. L. 2011. $113 \mathrm{C}$ evidence that high primary productivity delayed recovery from end-Permian mass extinction. Earth and Planetary Science Letters 302(3-4), 378-84.

Mussard, K. M., Le HiR, G., Fluteau, F., Lefebvre, V. \& Godderis, Y. 2014. Modeling the carbon-sulfate interplays in climate changes related to the emplacement of continental flood basalts. In Volcanism, Impacts, and Mass Extinctions (eds G. Keller and A. C. Kerr), Geological Society of America Special Paper 505, pp. 339-52.

OfFICER, C. B. \& DRAKE, C. L. 1983. The Cretaceous-Tertiary transition. Science 219(4591), 1383-90.

OFFICER, C. B. \& DRAKE, C. L. 1985. Terminal Cretaceous environmental events. Science 227(4691), 1161-67.

Officer, C. B., Hallam, A., DRAKe, C. L. \& DeVInE, J. D. 1987. Late Cretaceous and paroxysmal Cretaceous Tertiary extinctions. Nature 326(6109), 143-49.

OGDEN, D. E. \& SLEEP, N. H. 2012. Explosive eruption of coal and basalt and the end-Permian mass extinction. Proceedings of the National Academy of Sciences of the United States of America 109(1), 59-62.

Pagani, M., CALDEIRA, K., ARCher, D. \& ZaChos, J. C. 2006. An ancient carbon mystery. Science 314(5805), 1556-57.

PÄLICKE, C., DeLANEY, M. L. \& ZACHOS, J. C. 2014. Deep-sea redox across the Paleocene-Eocene thermal maximum. Geochemistry Geophysics Geosystems 15(4), 1038-53.

PAYNE, J. L. \& CLAPHAM, M. E. 2012. End-Permian Mass Extinction in the Oceans: An Ancient Analog for the Twenty-First Century? Annual Review of Earth and Planetary Sciences, Vol 40 40, 89-111.

PAYNE, J. L. \& KUMP, L. R. 2007. Evidence for recurrent Early Triassic massive volcanism from quantitative interpretation of carbon isotope fluctuations. Earth and Planetary Science Letters 256(1-2), 264-77.

Payne, J. L., Lehrmann, D. J., Follett, D., Seibel, M., Kump, L. R., Riccardi, A., Altiner, D., Sano, H. \& Wei, J. 2007. Erosional truncation of uppermost Permian shallow-marine carbonates and 
implications for Permian-Triassic boundary events. Geological Society of America Bulletin 119(7-8), 771-84.

Payne, J. L., Lehrmann, D. J., Wel, J., ORChARD, M. J., SChrag, D. P. \& KNOLL, A. H. 2004. Large perturbations of the carbon cycle during recovery from the end-Permian extinction. Science 305(5683), 506-09.

Payne, J. L., TURChyn, A. V., PAYTAN, A., DePaolo, D. J., Lehrmann, D. J., YU, M. \& Wel, J. 2010. Calcium isotope constraints on the end-Permian mass extinction. Proceedings of the National Academy of Sciences 107(19), 8543-48.

Penman, D. E., HönISCH, B., ZeEBE, R. E., Thomas, E. \& ZACHOS, J. C. 2014. Rapid and sustained surface ocean acidification during the Paleocene-Eocene Thermal Maximum. Paleoceanography 29(5), 2014 PA002621.

RACKI, G. 2012. The Alvarez impact theory of mass extinction; limits to its applicability and the "great expectations syndrome". Acta Palaeontologica Polonica 57(4), 681-702.

RACKI, G. \& WIGNALL, P. B. 2005. Late Permian double-phased mass extinction and volcanism: an oceanographic perspective. Developments in Palaeontology and Stratigraphy 20, 263-297.

RAMPINO, M. R. \& CALDEIRA, K. 2005. Major perturbation of ocean chemistry and a 'Strangelove Ocean' after the end-Permian mass extinction. Terra Nova 17(6), 554-59.

RAMPINO, M. R., SELF, S. \& StOTHERS, R. B. 1988. Volcanic winters. Annual Review of Earth and Planetary Science 16, 73-99.

RAMPINO, M. R. \& STOTHERS, R. B. 1988. Flood basalt volcanism during the past 250 million years. Science 241, 663-68.

RaUP, D. M. 1979. Size of the Permo-Triassic bottleneck and its evolutionary implications. Science 206(4415), 217-18.

RAVIZZA, G., NORRIS, R. N., BLUSZTAJN, J. \& AUBRY, M. P. 2001. An osmium isotope excursion associated with the Late Paleocene thermal maximum: Evidence of intensified chemical weathering. Paleoceanography 16(2), 155-63.

Reichow, M. K., Pringle, M. S., Al'Mukhamedov, A. I., Allen, M. B., AndreicheV, V. L., Buslov, M. M., Davies, C. E., Fedoseev, G. S., FitTon, J. G., Inger, S., MedvedeV, A. Y., Mitchell, C., Puchkov, V. N., SAFONOVA, I. Y., SCOTT, R. A. \& SAUNDERS, A. D. 2009. The timing and extent of the eruption of the Siberian Traps large igneous province: Implications for the end-Permian environmental crisis. Earth and Planetary Science Letters 277(1-2), 9-20.

Reichow, M. K., SAunders, A. D., White, R. V., Pringle, M. S., Al'Mukhamedov, A. I., Medvedev, A. \& KORDA, N. 2002. New 40Ar-39Ar data on basalts from the West Siberian Basin: Extent of the Siberian flood basalt province doubled. Science 296, 1846-49.

RENNE, P. R. \& BASU, A. R. 1991. Rapid eruption of the Siberian Traps flood basalts at the PermoTriassic boundary. Science 253, 176-79.

Renne, P. R., SWisher, C. C., Deino, A. L., KARner, D. B., OWens, T. L. \& DePaolo, D. J. 1998. Intercalibration of standards, absolute ages and uncertainties in 40Ar/39Ar dating. Chemical Geology 145(1-2), 117-52.

RENNE, P. R., ZICHAO, Z., RICHARDS, M. A., BLACK, M. T. \& BASU, A. R. 1995. Synchrony and causal relations between Permian-Triassic boundary crises and Siberian flood volcanism. Science 269, 1413-16.

RETALLACK, G. J. \& JAHREN, A. H. 2008. Methane release from igneous intrusion of coal during Late Permian extinction events. Journal of Geology 116, 1-20.

RETALLACK, G. J. \& KRULL, E. S. 2006. Carbon isotopic evidence for terminal-Permian methane outbursts and their role in extinctions of animals, plants, coral reefs, and peat swamps. In Special Paper of the Geological Society of America pp. 249-68.

RICCARDI, A., KUMP, L. R., ARTHUR, M. A. \& D'HONDT, S. 2007. Carbon isotopic evidence for chemocline upward excursions during the end-Permian event. Palaeogeography, Palaeoclimatology, Palaeoecology 248(1-2), 73-81. 
RICCARDI, A. L., ARTHUR, M. A. \& KUMP, L. R. 2006. Sulfur isotopic evidence for chemocline upward excursions during the end-Permian mass extinction. Geochimica et Cosmochimica Acta 70(23), 5740-52.

RICHARDS, M. A., DUNCAN, R. A. \& COURTILLOT, V. E. 1989. Flood basalts and hot-spot tracks: plume heads and tails. Science 246, 103-07.

ROHL, U., WeSterHold, T., BRALOWER, T. J. \& ZACHOS, J. C. 2007. On the duration of the PaleoceneEocene thermal maximum (PETM). Geochemistry Geophysics Geosystems 8. Q12002.

Ross, P.-S., Ukstins-Peate, I., McClintock, M. K., XU, Y. G., SKILling, I. P., White, J. D. L. \& HOUGHTON, B. F. 2005. Mafic volcaniclastic deposits in flood basalt provinces: A review. Journal of Volcanology and Geothermal Research 145, 281-314.

SAUNDERS, A. \& REICHOW, M. 2009. The Siberian Traps and the End-Permian mass extinction: a critical review. Chinese Science Bulletin 54(1), 20-37.

SAUnders, A. D., ENGLAND, R. W., Reichow, M. K. \& White, R. V. 2005. A mantle plume origin for the Siberian Traps: uplift and extension in the West Siberian Basin, Russia. Lithos 79, 407-24.

Saunders, A. D., Fitton, J. G., KerR, A. C., NorRY, M. J. \& KeNT, R. W. 1997. The North Atlantic Igneous Province. In Large Igneous Provinces: Continental, Oceanic, and Planetary Flood Volcanism (eds J. J. Mahoney and M. F. Coffin). pp. 45-93. American Geophysical Union Monograph 100.

SAunders, A. D., Jones, S. M., Morgan, L. A., PIerCE, K. L., Widdowson, M. \& XU, Y. G. 2007. Regional uplift associated with continental large igneous provinces: The roles of mantle plumes and the lithosphere. Chemical Geology 241(3-4), 282-318.

SAUNDERS, A. D., LARSEN, H. C. \& FitTon, J. G. 1998. Magmatic development of the southeast Greenland margin and evolution of the Iceland plume: geochemical constraints from Leg 152. eds A. D. Saunders, H. C. Larsen and S. W. j. Wise). pp. 479-501. College Station, TX: Ocean Drilling Program.

Schulte, P., Alegret, L., Arenillas, I., Arz, J. A., Barton, P. J., Bown, P. R., Bralower, T. J., Christeson, G. L., Claeys, P., Cockell, C. S., Collins, G. S., DeUtsch, A., Goldin, T. J., Goto, K., Grajales-Nishimura, J. M., GRIEVE, R. A. F., GULICK, S. P. S., JOHnSON, K. R., KIESSLING, W., KOEBERL, C., KRING, D. A., Macleod, K. G., Matsui, T., Melosh, J., Montanari, A., Morgan, J. V., Neal, C. R., Nichols, D. J., Norris, R. D., Pierazzo, E., Ravizza, G., Rebolledo-Vieyra, M., Reimold, W. U., Robin, E., Salge, T., SPEIJER, R. P., SWeet, A. R., URRUtiA-FuCUGauChi, J., VAJdA, V., Whalen, M. T. \& Willumsen, P. S. 2010. The Chicxulub Asteroid Impact and Mass Extinction at the Cretaceous-Paleogene Boundary. Science 327(5970), 1214-18.

SELF, S., BLAKE, S., SHARMA, K., WIDDOWSON, M. \& SEPHTON, S. 2008. Sulfur and chlorine in Late Cretaceous Deccan magmas and eruptive gas release. Science 319(5870), 1654-57.

SELF, S., THORDARSON, T. \& WIDDOWSON, M. 2005. Gas fluxes from flood basalt eruptions. Elements $1(5), 283-87$.

SELF, S., WidDowson, M., THORDARSON, T. \& JAY, A. E. 2006. Volatile fluxes during flood basalt eruptions and potential effects on the global environment: A Deccan perspective. Earth and Planetary Science Letters 248(1-2), 517-31.

ShARMA, M. 1997. Siberian Traps. In Large Igneous Provinces: Continental, Oceanic, and Planetary Flood Volcanism (eds J. J. Mahoney and M. F. Coffin). American Geophysical Union Monograph 100, pp 273-95.

Shen, J., AlgeO, T. J., ZHOU, L., FenG, Q., Yu, J. \& ElLWOOD, B. 2012. Volcanic perturbations of the marine environment in South China preceding the latest Permian mass extinction and their biotic effects. Geobiology 10(1), 82-103.

Shen, S. Z., Crowley, J. L., Wang, Y., Bowring, S. A., ErWin, D. H., Sadler, P. M., CaO, C. Q., Rothman, D. H., Henderson, C. M., RAmezani, J., Zhang, H., Shen, Y. N., WANG, X. D., WANG, W., Mu, L., LI, W. Z., TANG, Y. G., LIU, X. L., LIU, L. J., ZENG, Y., JIANG, Y. F. \& JIN, Y. G. 2011. Calibrating the End-Permian Mass Extinction. Science 334(6061), 1367-72.

SINTON, C. W., HITCHEN, K. \& DUNCAN, R. A. 1998. ${ }^{40} \mathrm{Ar}-{ }^{39} \mathrm{Ar}$ geochronology of silicic and basic volcanic rocks on the margins of the North Atlantic. Geological Magazine 135(2), 161-70. 

injection at the Palaeocene/Eocene boundary. Nature 450(7173), 1218-21.

SMIRNOV, A. V. \& TARDUNO, J. A. 2010. Co-location of eruption sites of the Siberian Traps and North Atlantic Igneous Province: Implications for the nature of hotspots and mantle plumes. Earth and Planetary Science Letters 297(3-4), 687-90.

Sobolev, S. V., Sobolev, A. V., Kuzmin, D. V., Krivolutskaya, N. A., Petrunin, A. G., Arndt, N. T., Radko, V. A. \& VASILIEV, Y. R. 2011. Linking mantle plumes, large igneous provinces and environmental catastrophes. Nature 477(7364), 312-16.

Song, H., WignalL, P. B., TONG, J. \& YIN, H. 2013. Two pulses of extinction during the Permian-Triassic crisis. Nature Geoscience 6(1), 52-56.

Song, H., Tong, J., AlgeO, T. J., HoraCEK, M., QIU, H., SONG, H., TiAN, L. \& CHEN, Z.-Q. 2013. Large vertical $\delta^{13} C_{D I C}$ gradients in Early Triassic seas of the South China craton: Implications for oceanographic changes related to Siberian Traps volcanism. Global and Planetary Change 105(0), 7-20.

Storey, M., DUNCAN, R. A. \& SWISHER, C. C. 2007. Paleocene-Eocene thermal maximum and the opening of the northeast Atlantic. Science 316(5824), 587-89.

STOREY, M., DUNCAN, R. A. \& TEGNER, C. 2007. Timing and duration of volcanism in the North Atlantic Igneous Province: Implications for geodynamics and links to the Iceland hotspot. Chemical Geology 241(3-4), 264-81.

StOTHERS, R. B. 1993. Flood basalts and extinction events. Geophysical Research Letters 20(13), 1399402.

Stothers, R. B., WolfF, J. A., SelF, S. \& RAMPINO, M. R. 1986. Basaltic fissure eruptions, plume heights, and atmospheric aerosols. Geophysical Research Letters 13(8), 725-28.

SUn, Y., JOACHIMSKI, M. M., WIGNALL, P. B., YAN, C., CHEN, Y., JIANG, H., WANG, L. \& LAI, X. 2012. Lethally hot temperatures during the early Triassic greenhouse. Science 338(6105), 366-70

Svensen, H., Planke, S., Chevallier, L., Malthe-Sorenssen, A., Corfu, F. \& Jamtveit, B. 2007. Hydrothermal venting of greenhouse gases triggering Early Jurassic global warming. Earth and Planetary Science Letters 256(3-4), 554-66.

SVENSEN, H., PLANKE, S. \& CoRfu, F. 2010. Zircon dating ties NE Atlantic sill emplacement to initial Eocene global warming. Journal of the Geological Society of London 167, 433-36.

SVensen, H., Planke, S., Malthe-Sørenssen, A., JamtVeit, B., Myklebust, R., Eidem, T. R. \& Rey, S. S. 2004. Release of methane from a volcanic basin as a mechanism for initial Eocene global warming. Nature 429, 542-45.

SVensen, H., Planke, S., Polozov, A. G., Schmidbauer, N., Corfu, F., Podladchikov, Y. Y. \& Jamtveit, B. 2009a. Siberian gas venting and the end-Permian environmental crisis. Earth and Planetary Science Letters 277(3-4), 490-500.

SVensen, H., SChmidbauer, N., Roscher, M., Stordal, F. \& Planke, S. 2009b. Contact metamorphism, halocarbons, and environmental crises of the past. Environmental Chemistry 6(6), 466-71.

TAKAHASHI, S., KAIHO, K., OBA, M. \& KAKEGAWA, T. 2010. A smooth negative shift of organic carbon isotope ratios at an end-Permian mass extinction horizon in central pelagic Panthalassa. Palaeogeography, Palaeoclimatology, Palaeoecology 292(3-4), 532-39.

TAKAHASHI, S., OBA, M., KaIHO, K., YAMAKITA, S. \& SAKATA, S. 2009. Panthalassic oceanic anoxia at the end of the Early Triassic: A cause of delay in the recovery of life after the end-Permian mass extinction. Palaeogeography, Palaeoclimatology, Palaeoecology 274(3-4), 185-95.

TAKAHASHI, S., YAMASAKI, S.-I., OgAWA, Y., KIMURA, K., KAIHO, K., YOSHIDA, T. \& TSUCHIYA, N. 2014. Bioessential element-depleted ocean following the euxinic maximum of the end-Permian mass extinction. Earth and Planetary Science Letters 393, 94-104.

Thomas, B. C., Melott, A. L., Jackman, C. H., Laird, C. M., MedvedeV, M. V., Stolarski, R. S., Gehrels, N., CANNIZZO, J. K., HOGAN, D. P. \& EJZAK, L. M. 2005. Gamma-ray bursts and the earth: Exploration 
of atmospheric, biological, climatic, and biogeochemical effects. Astrophysical Journal 634(1), 509-33.

THOMAS, D. J., ZACHOS, J. C., BRALOWER, T. J., THOMAS, E. \& BOHATY, S. 2002. Warming the fuel for the fire: evidence for the thermal dissociation of methane hydrate during the Paleocene-Eocene thermal maximum. Geology 30(12), 1067-70.

THOMAS, E. 1989. Development of Cenozoic deep-sea benthic foraminiferal faunas in Antarctic waters. Geological Society, London, Special Publications 47(1), 283-96.

THOMAS, E. \& SHACKLETON, N. J. 1996. The Paleocene-Eocene benthic foraminiferal extinction and stable isotope anomalies. Correlation of the early Paleogene in northwest Europe, 401-41.

THOMSON, K. 2004. Sill complex geometry and internal architecture: a 3D seismic perspective. In Physical Geology of High-Level Magmatic Systems (eds C. Breitkreuz and N. Petford). Geological Society of London Special Publication 234, pp. 229-32.

THORDARSON, T. \& SELF, S. 1996. Sulfur, chlorine and fluorine degassing and atmospheric loading by the Roza eruption, Columbia River Basalt Group, Washington, USA. Journal of Volcanology and Geothermal Research 74, 49-73.

THORDARSON, T. \& SELF, S. 2003. Atmospheric and environmental effects of the 1783-1784 Laki eruption: a review and reassessment. Journal of Geophysical Research 107.

THORDARSON, T., SELF, S., OSKARSSON, N. \& HULSEBOCH, T. 1996. Sulfur, chlorine, and fluorine degassing and atmospheric loading by the 1783-1784 AD Laki (Skaftár Fires) eruption in Iceland. Bulletin Volcanologique 58, 205-25.

Tolan, T. L., Reidel, S. P., BeEson, M. H., ANDERSON, J. L., FeCht, K. R. \& SWANSON, D. A. 1989. Revisions to the estimates of the areal extent and volume of the Columbia River Basalt Group. In Special Paper of the Geological Society of America 239, pp. 1-20.

TWITCHET, R. J. 2007. Climate change across the Permo-Triassic boundary. In Deep-Time Perspectives on Climate Change: Marrying the Signal from Computer models and Biological Proxies (eds M. Williams, A. M. Haywodd, F. J. Gregory and D. N. Schmidt). Special Publication of the Micropalaeontological Society, pp. 191-200. London: The Geological Society.

TWITCHETT, R. J., LOOY, C. V., MORANTE, R., VISSCHER, H. \& WIGNALL, P. B. 2001. Rapid and synchronous collapse of marine and terrestrial ecosystems during the end-Permian biotic crisis. Geology 29(4), 351-54.

TYRRELL, G. W. 1937. Flood basalts and fissure eruptions. Bulletin of Volcanology 1, 89-111.

VOGT, P. R. 1972. Evidence for global synchronism in mantle plume convection, and possible significance for geology. Nature 240(5380), 338-42.

WANG, Y., SAdleR, P. M., Shen, S.-Z., ERWIN, D. H., ZHANG, Y.-C., WANG, X.-D., WANG, W., CroWleY, J. L. \& HENDERSON, C. M. 2014. Quantifying the process and abruptness of the end-Permian mass extinction. Paleobiology 40(1), 113-29.

WeSTERHOLD, T., ROEHL, U. \& LASKAR, J. 2012. Time scale controversy: Accurate orbital calibration of the early Paleogene. Geochemistry Geophysics Geosystems 13.

WHITE, R. S. \& MCKENZIE, D. P. 1989. Magmatism at rift zones: the generation of volcanic continental margins and flood basalts. J. geophys. Res. 94, 7685-729.

White, R. S., SPenCe, G. D., Fowler, S. R., MCKenzie, D. P., Westbrook, G. K. \& Bowen, A. N. 1987. Magmatism at rifted continental margins. Nature 330, 439-44.

WHITE, R. V. \& SAUNDERS, A. D. 2005. Volcanism, impact and mass extinctions: incredible or credible coincidences. Lithos 79, 299-316.

Wieczorek, R., FANTLE, M. S., KUMP, L. R. \& RAVIZZA, G. 2013. Geochemical evidence for volcanic activity prior to and enhanced terrestrial weathering during the Paleocene Eocene Thermal Maximum. Geochimica et Cosmochimica Acta 119, 391-410.

WIGNALL, P. B. 2001. Large igneous provinces and mass extinctions. Earth-Science Reviews 53(1-2), 133. 
WiGnALL, P. B. \& HALLAM, A. 1992. Anoxia as a cause of the Permian/Triassic mass extinction: facies evidence from northern Italy and the western United States. Palaeogeography, Palaeoclimatology, Palaeoecology 93(1-2), 21-46.

Wignall, P. B., Morante, R. \& NeWton, R. 1998. The Permo-Triassic transition in Spitsbergen: $\delta^{13} C_{\text {org }}$ chemostratigraphy, Fe and $\mathrm{S}$ geochemistry, facies fauna and trace fossils. Geological Magazine 135(1), 47-62.

WignALL, P. B. \& NEWTON, R. 2003. Contrasting deep-water records from the Upper Permian and Lower Triassic of South Tibet and British Columbia: Evidence for a diachronous mass extinction. Palaios 18(2), 153-67.

WIGNALL, P. B. \& TWITCHETT, R. J. 1996. Oceanic anoxia and the end Permian mass extinction. Science 272, 1155-58.

Wooden, J. L., Czamanske, G. K., Fedorenko, V. A., Arndt, N. T., Chauvel, C., Bouse, R. M., King, B. W., KNIGHT, R. J. \& SIEMS, D. F. 1993. Isotopic and trace-element constraints on mantle and crustal contributions to Siberian continental flood basalts, Noril'sk area, Siberia. Geochimica et Cosmochimica Acta 57, 3677-704.

WotZlAW, J.-F., BindemAN, I. N., SCHALTEGger, U., BROOKS, C. K. \& NASLUND, H. R. 2012. High-resolution insights into episodes of crystallization, hydrothermal alteration and remelting in the Skaergaard intrusive complex. Earth and Planetary Science Letters 355-356(0), 199-212.

WRIGHT, J. D. \& SCHALLER, M. F. 2013. Evidence for a rapid release of carbon at the Paleocene-Eocene thermal maximum. Proceedings of the National Academy of Sciences 110(40), 15908-13.

ZACHOS, J. C., MCCARREN, H., MURPhy, B., ROEHL, U. \& WeSTERHOLD, T. 2010. Tempo and scale of late Paleocene and early Eocene carbon isotope cycles: Implications for the origin of hyperthermals. Earth and Planetary Science Letters 299(1-2), 242-49.

ZACHOS, J., PAGANI, M., SLOAN, L., THOMAS, E. \& BILLUPS, K. 2001. Trends, rhythms, and aberrations in global climate $65 \mathrm{Ma}$ to present. Science 292(5517), 686-93.

ZaChos, J. C., RöHL, U., SChellenberg, S. A., Sluiss, A., Hodell, D. A., Kelly, D. C., Thomas, E., Nicola, M., RAFFI, I., LOURENS, L. J., MCCARREN, H. \& KROON, D. 2005. Rapid acidification of the ocean during the Paleocene-Eocene thermal maximum. Science 308, 16-16.

Zachos, J. C., WARA, M. W., Bohaty, S., Delaney, M. L., Petrizzo, M. R., Brill, A., Bralower, T. J. \& PREMOLI-SILVA, I. 2003. A transient rise in tropical sea surface temperature during the Paleocene-Eocene Thermal Maximum. Science 302(5650), 1551-54.

ZeEbE, R. E. 2013. What caused the long duration of the Paleocene-Eocene Thermal Maximum? Paleoceanography 28(3), 440-52. 


\section{Figure Captions}

Figure 1. Maps of the North Atlantic and Siberian large igneous provinces, drawn to approximately the same scale, to demonstrate the relative sizes and configurations of the two provinces. (a) North Atlantic Igneous Province at 55-60 Ma, prior to full separation of the North American and Eurasian plates. 'Law Mul 5560 Ma' refer to proposed locations of the axis of the Iceland plume at 55 and $60 \mathrm{Ma}$ (Lawver \& Müller, 1994). Modified after Saunders et al. (1997). (b) Siberian large igneous province (present-day configuration), from Saunders \& Reichow (2009). (Ur: Urengoy Rift; Kh: Khudosey Rift.)

Figure 2. $\mathrm{Sm} / \mathrm{Yb}$ (chondrite normalised) in basalts from the NAIP (SE Greenland margin) and Siberian Traps (Noril'sk). The progressive reduction of $\mathrm{Sm} / \mathrm{Yb}$ upwards through both sequences of basalts suggests temporal shallowing of the average depth of melting, consistent with thinning of the lithosphere due to extension and/or delamination. NAIP plot modified after Saunders, Larsen and Fitton (1998). Siberian Traps data, including the names of the main lava formations at Noril'sk, from (Lightfoot et al., 1990; Wooden et al., 1993; Hawkesworth et al., 1995).

Figure 3. $\delta^{13} \mathrm{C}, \delta^{18} \mathrm{O}$ and calculated seawater temperatures in the Palaeocene and Eocene (a) and across the PETM (b). Data in (a) are from Zachos et al. (2001), and mostly represent data from specific taxa. Estimates for the age of the NAIP are from Saunders et al. (1997) and Storey et al. (2007a,b). Data in panel (b) are from Bains et al. (1999), and are from bulk carbonate analyses. The age of the onset of the PETM is from Westerhold et al. (2012), and the estimated duration of the PETM is taken from Röhl et al. (2007).

Figure 4. Age data associated with the PETM and the Phase 2 activity of the North Atlantic Igneous Province. Because of discrepancies between ${ }^{40} \mathrm{Ar}-{ }^{39} \mathrm{Ar}, \mathrm{U}-\mathrm{Pb}$ and astronomically calibrated ages, all of the data are referenced relative to the onset of the PETM (right-hand scale). Absolute age scales are adjusted relative to the 
PETM. The offset between Ash Bed -17 and the PETM is taken from Westerhold et al. (2012). Data sources: Voring sills : Svensen et al. (2010); Skaergaard intrusion: Wotzlaw et al. (2012); Longyearbyen Tuff: Charles et al. (2011); East Greenland and Faroes basalts and Skraenterne Tuff: Storey et al. $(2007, \mathrm{a}, \mathrm{b})$ (FCs $=28.02$ Ma); PETM CIE: Figure 3, this paper; astronomically-calibrated ages: Westerhold et al. (2012).

Figure 5. High-precision U-Pb ages for zircons from ash horizons at the Meishan GSSP, China (Burgess et al., 2014). Carbon isotope data from Cao et al. $(2002,2009)$; extinction interval from Shen et al. (2011) and Wang et al. (2014). Inset: Composite $\delta^{13} \mathrm{C}$ isotope curve from the late Permian to the end of the Middle Triassic, demonstrating strong fluctuations in the global carbon isotope record throughout the Early Triassic (modified from Payne et al., 2007) (abbreviations: Pm: Permian; Ch: Changhsingian; Gr: Griesbachian; Di: Dienerian; Sm: Smithian; Sp: Spathian).

Figure 6. Carbon-carbon isotope mixing lines for sources with different $\delta^{13} \mathrm{C}$ isotope values added to ocean-atmosphere systems containing a) 50,000 GtC $\left(\delta^{13} \mathrm{C}=0\right)$ and b) $100,000 \mathrm{GtC}\left(\delta^{13} \mathrm{C}=0\right)$. Each mixing curve has a designated $\delta^{13} \mathrm{C}$ value; the $\delta^{13} \mathrm{C}$ fields for the main carbon sources are from Maslin \& Thomas (2003). Example: for figure a), addition of $10,000 \mathrm{Gt}$ ( $\mathrm{x}$-axis) of carbon from methane hydrate $\left(\delta^{13} \mathrm{C}\right.$ $60 \%$ ) will decrease the $\delta^{13} \mathrm{C}$ of this ocean-atmosphere system by $10 \%$ (y-axis). 
Table 1. Estimates of masses of volatile elements released from flood basalts

\begin{tabular}{|c|c|c|}
\hline & $\begin{array}{c}\text { Volume of flow } \\
(\mathrm{km} 3)\end{array}$ & \multicolumn{2}{|c|}{ Mass of gas released (Mt) } \\
\cline { 3 - 4 } & $\mathrm{Cl} F$
\end{tabular}

\begin{tabular}{|l|c|c|c|c|cr|}
\cline { 3 - 7 } & $(\mathrm{km} 3)$ & $\mathrm{S}$ & $\mathrm{Cl}$ & $\mathrm{F}$ & $\mathrm{C}$ & \\
\hline Laki 1783 & 14.7 & & 61 & 6.6 & 14.3 & 95.1 \\
\hline
\end{tabular}

\begin{tabular}{|l|l|l|l|r|r|}
\hline Roza Flow, CRBG & 1300 & 6210 & 689 & 1691 & nd \\
\hline
\end{tabular}

\begin{tabular}{|c|c|c|}
\hline Roza Flow, CRBG & 1300 & 4800 \\
\hline
\end{tabular}

Ginkgo Flow, CRBG $\quad 1370$

Ginkgo Flow, CRBG

Ginkgo Flow, CRBG

\begin{tabular}{|l|l}
\hline Sand Hollow Flow, CRBG & 2660 \\
\hline Sentinel Gap Flow, CRBG & 1190 \\
\hline
\end{tabular}

Mahabaleshwar flows, Deccan nd

Siberian Traps - Lavas $\quad$ nd

Siberian Traps - Sills

Siberian Traps- lavas

nd

*The petrologic method involves direct analysis of glass melt inclusions and matrix glass; the proxy method employed by Blake et al (2010) allows estimate of gas content by using whole rock iron content to estimate the amount of sulphur in the magma where suitable melt inclusions may not be present.

Two LIPs and two mass extinctions $\Delta c$

4600 nd nd

$5500 \quad$ nd

$\frac{\text { Mass of gas released per } \mathrm{km}^{3}(\mathrm{Mt})}{\mathrm{S} \quad \mathrm{Cl} \quad \mathrm{F} \quad \mathrm{C}}$ Notes Petrologic method

Petrologic method Proxy method

Petrologic method nd nd

nd nd nd

nd $\quad 3.28$

nd

nd

1.78

nd nd

1 nd

nd Proxymethod

Petrologic method

Petrologic method

Petrologic method

References

Thordarson et al $(1996,2003)$ Thordarson and Self (1996)

Blake et al (2010) Blake et al (2010)

Blake et al (2010) Blake et al (2010) Blake et al (2010) Blake et al (2010)

Self et al (2008)

Black et al (2012)

Black et al (2012)

Saunders and Reichow (2009) 
Two LIPs and two mass extinctions

2

3

4

5

6

7

8

9

10

11

12

13

14

15

16

17

18

19

20

21

22

23

24

25

26

27

28

29

30

31

32

33

34

35

36

37

38

39

40

41

42

43

44

45

46

47

48

49

50

51

52

53

54

55

56

57

58

59

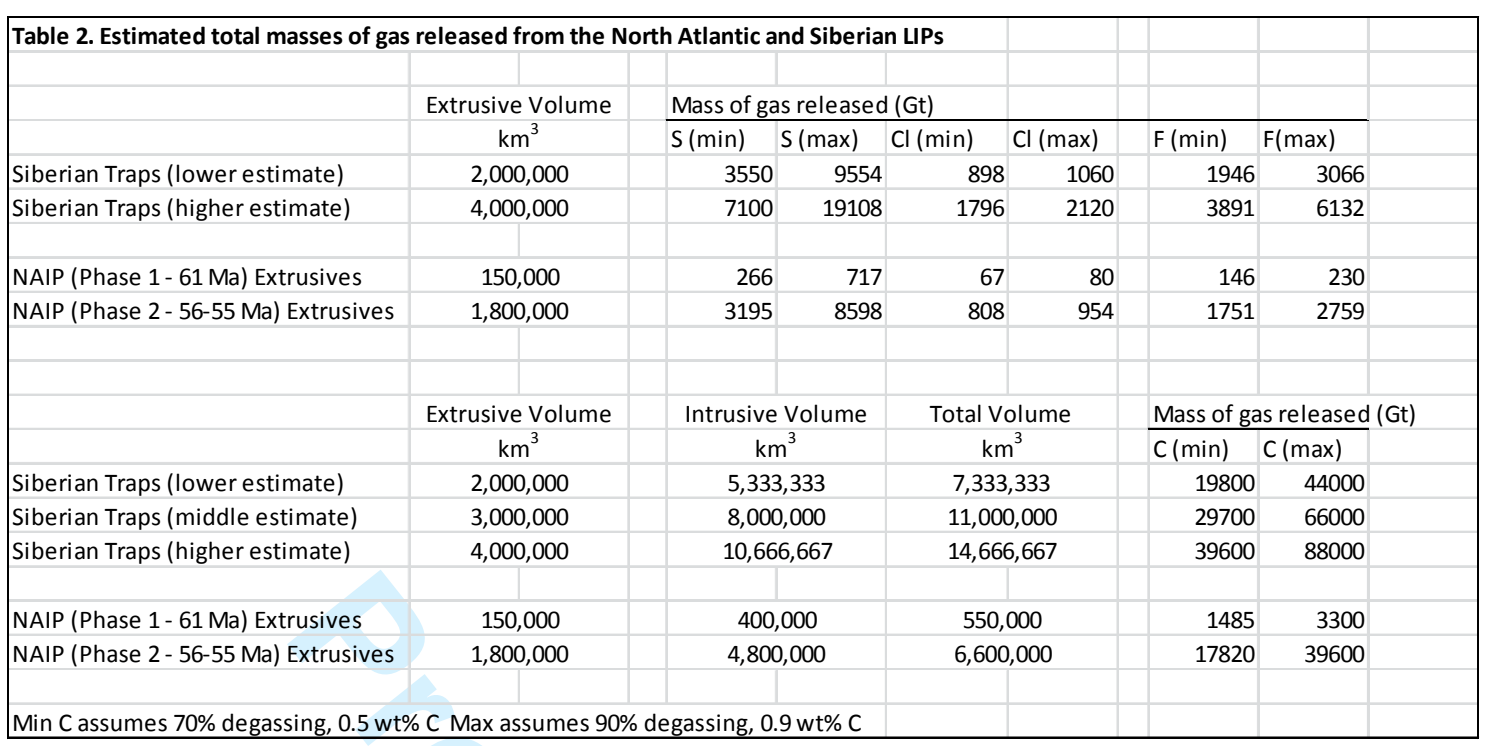




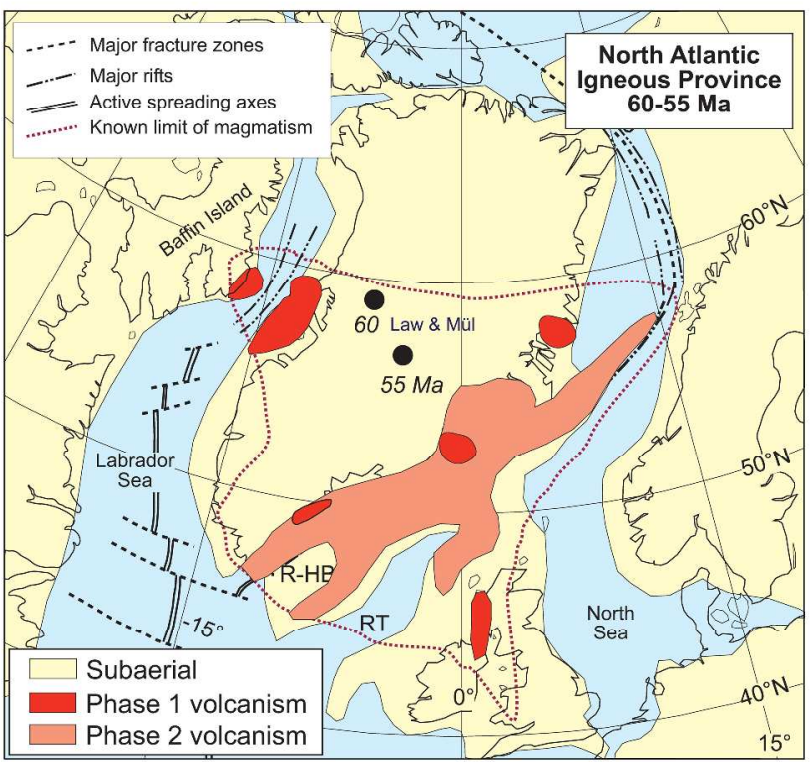

a)

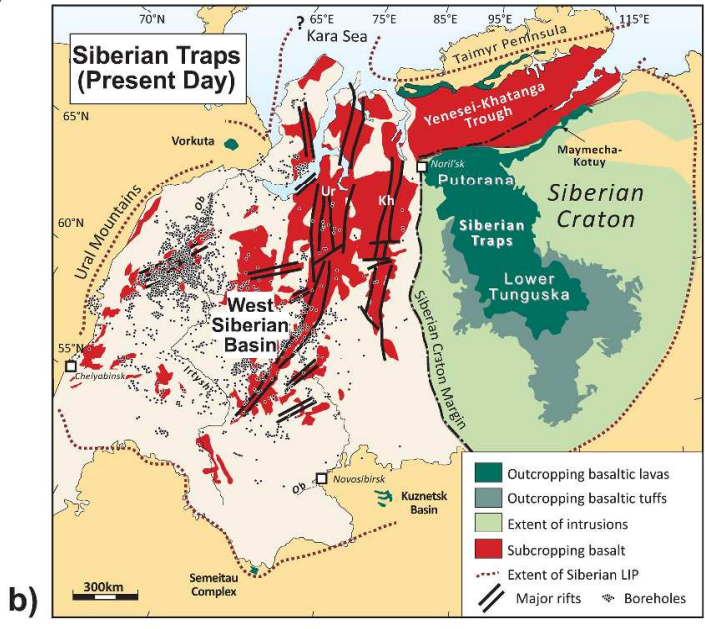

Figure 1

$403 \times 650 \mathrm{~mm}(300 \times 300$ DPI $)$ 


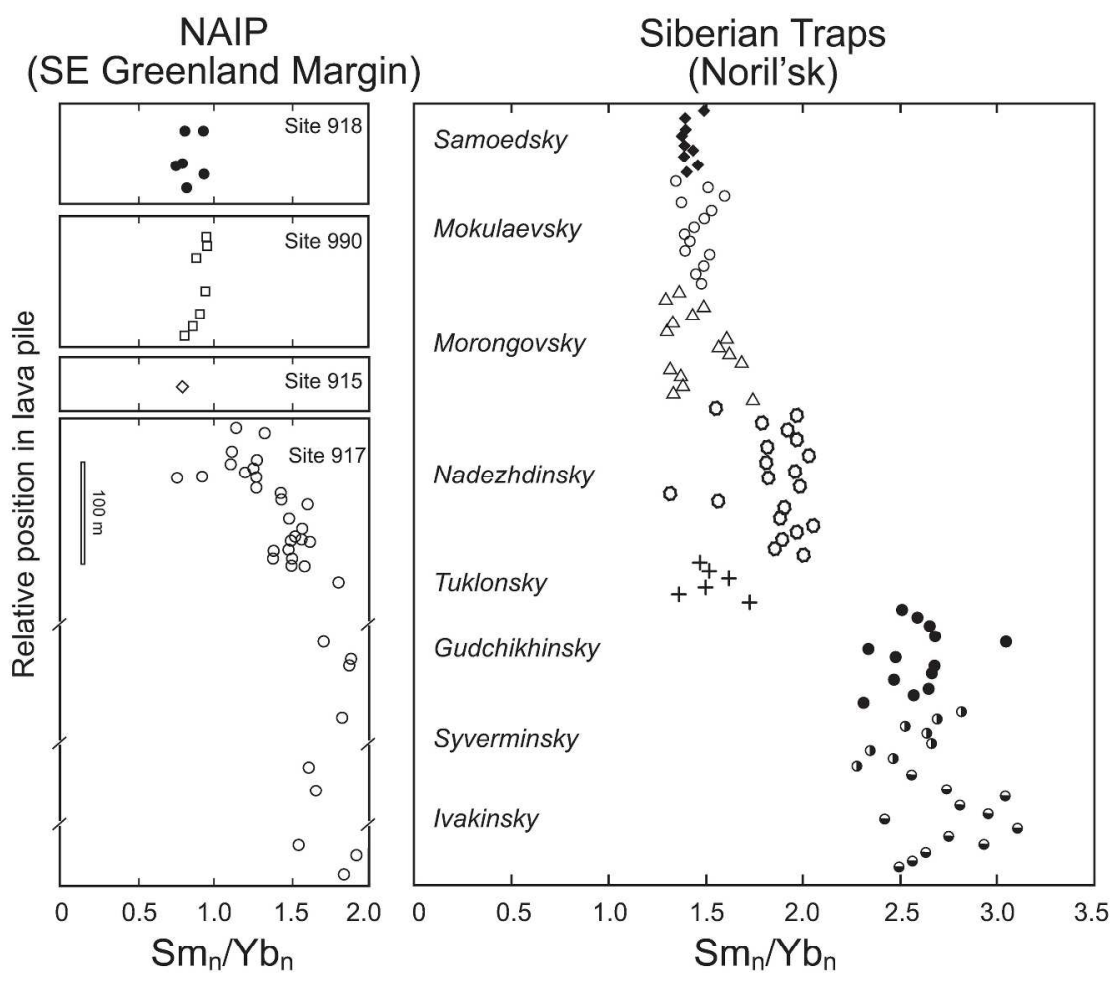

Figure 2 


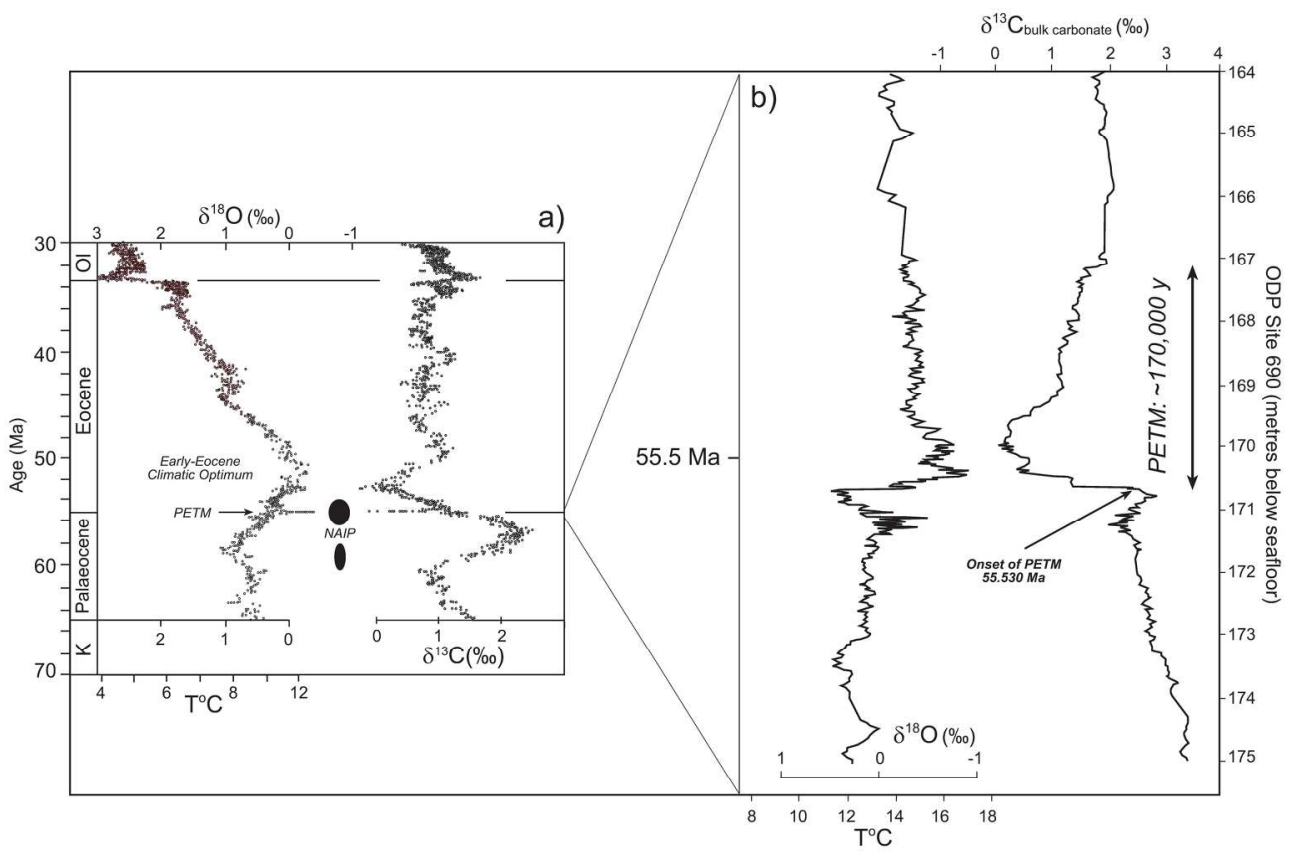

Figure 3

$188 \times 129 \mathrm{~mm}(300 \times 300 \mathrm{DPI})$ 


\section{Page 53 of 55}

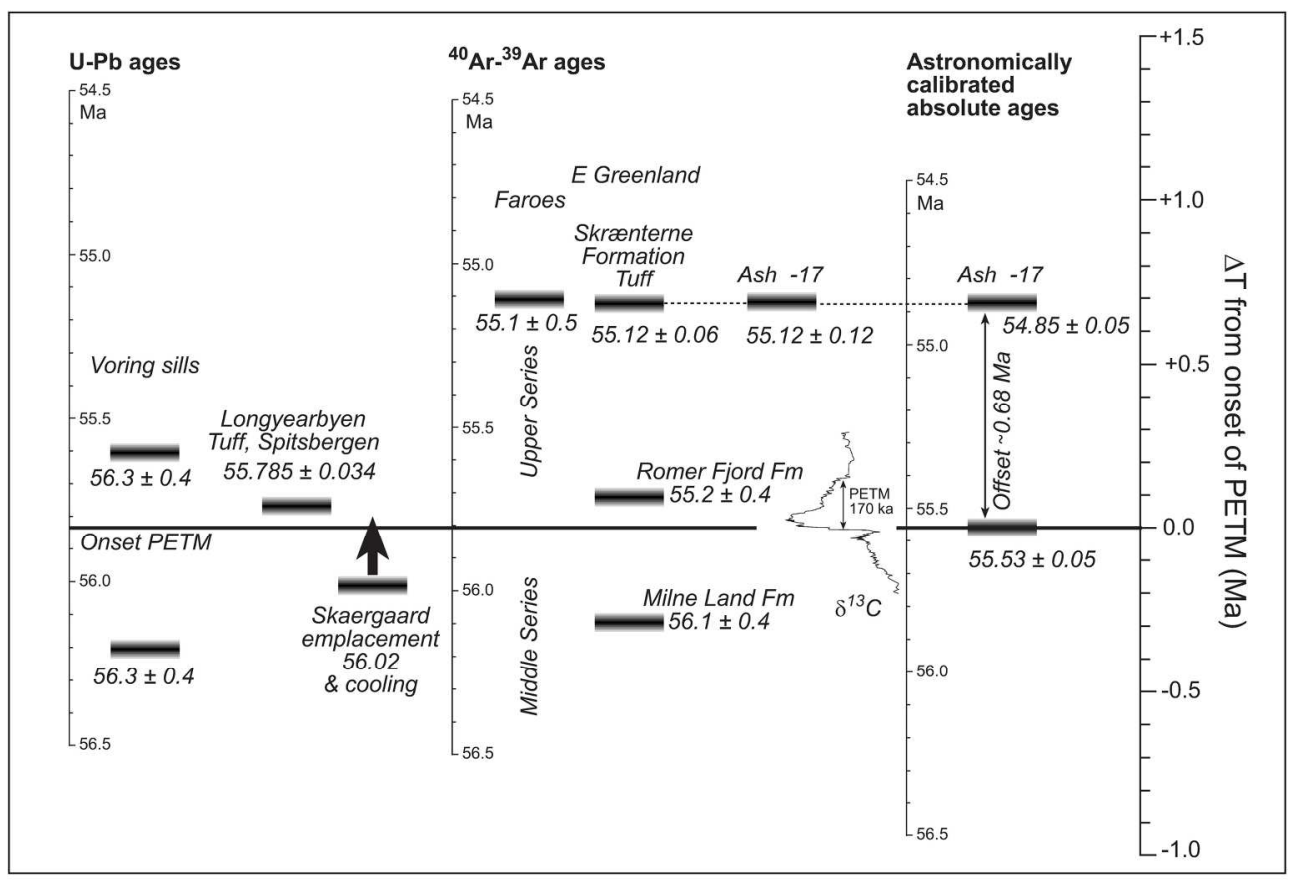

Figure 4

$197 \times 139 m m(300 \times 300$ DPI $)$ 


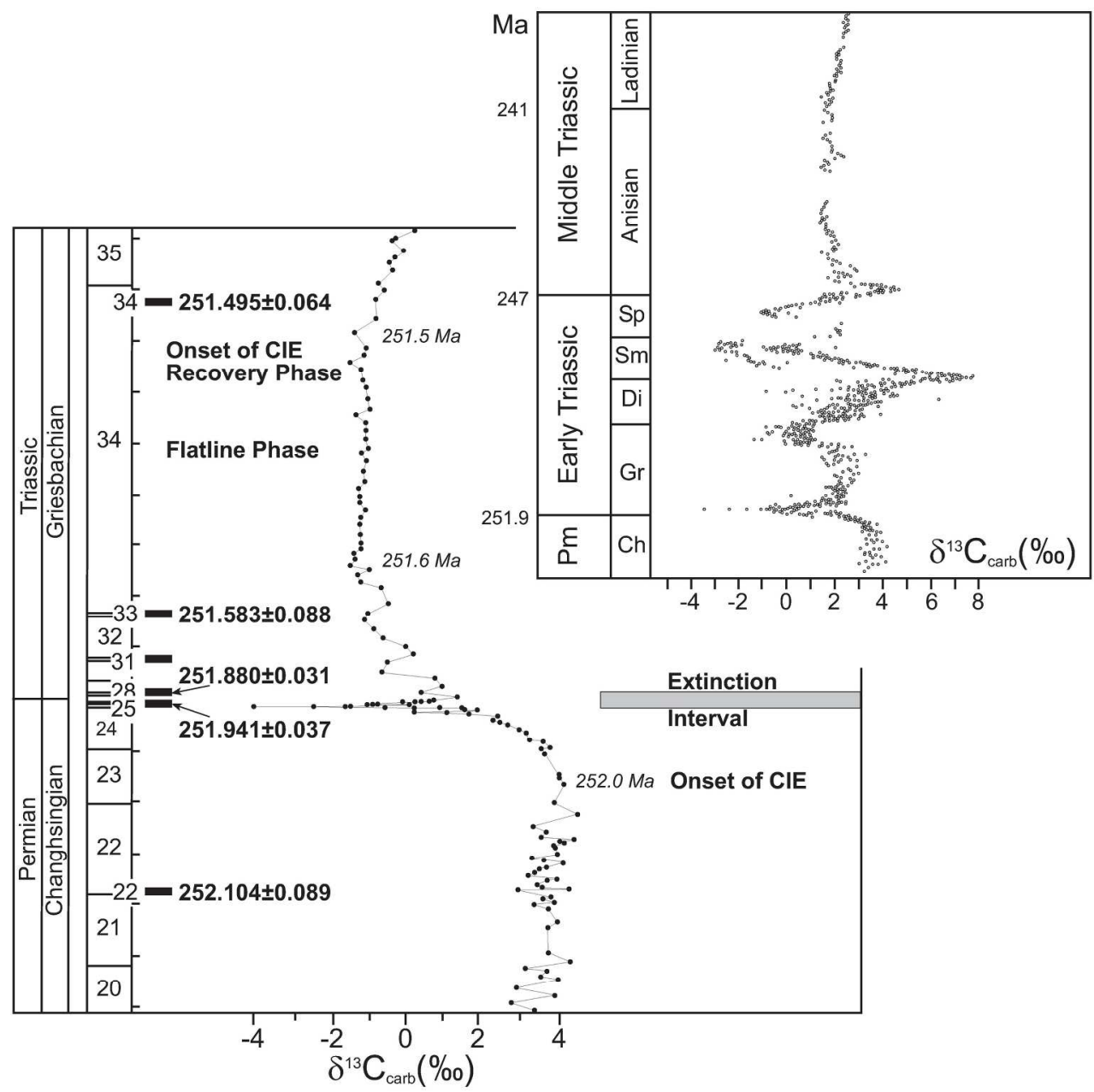

Figure 5

$208 \times 254 \mathrm{~mm}(300 \times 300 \mathrm{DPI})$ 


\section{Page 55 of 55}

2

3

4

5

6

7

8

9

10

11

12

13

14

15

16

17

18

19

20

21

22

23

24

25

26

27

28

29

30

31

32

33

34

35

36

37

38

39

40

41

42

43

44

45

46

47

48

49

50

51

52

53

54

55

56

57

58

59

60
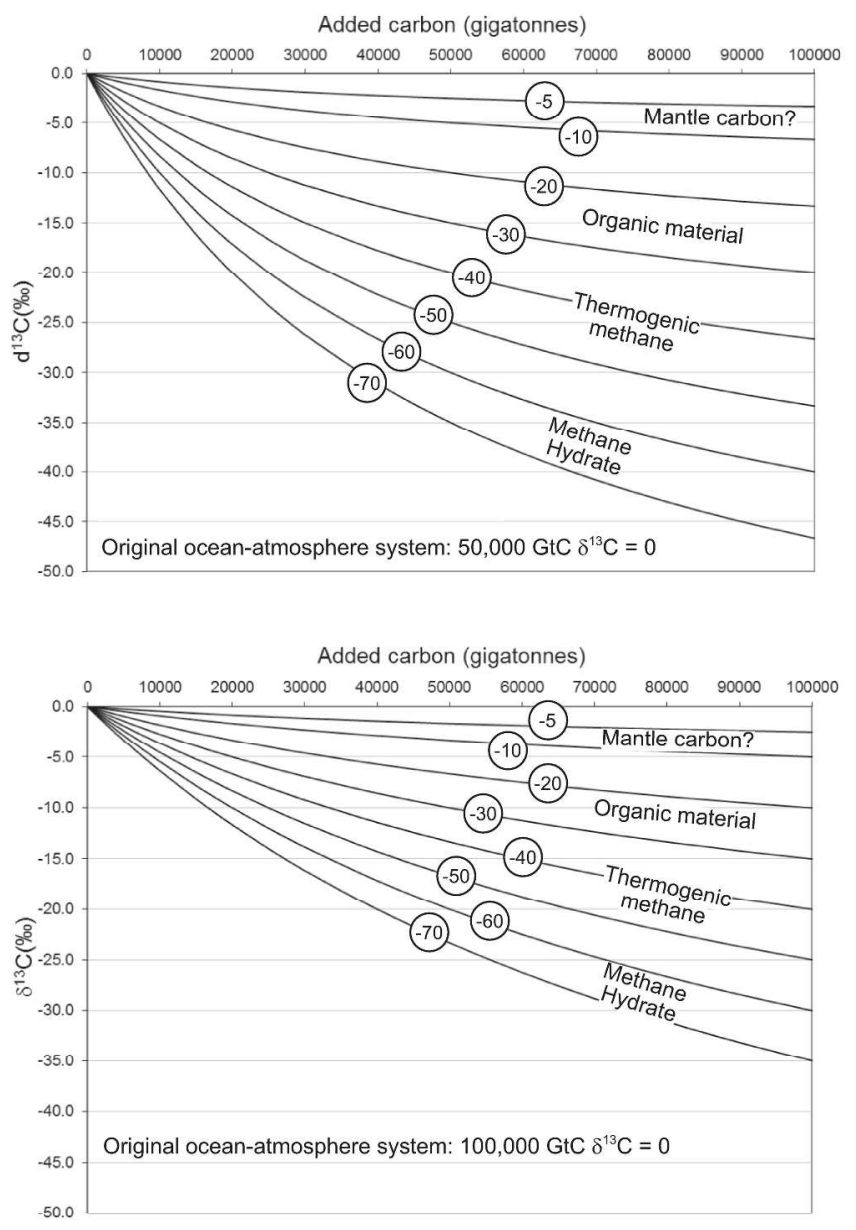

Figure 6

$235 \times 346 \mathrm{~mm}(300 \times 300 \mathrm{DPI})$ 